\title{
REDISCOVERY OF THE STEPPE VIPER IN GEORGIA
}

\author{
B.S. Tuniyev ${ }^{1 *}$, G.N. Iremashvili², T.V. Petrova ${ }^{1,3}$ and M.V. Kravchenko ${ }^{1}$ \\ ${ }^{1}$ Federal State Institution Sochi National Park, Moskovskaya Str. 21, 354000 Sochi, Russia; e-mails: btuniyev@mail.ru, \\ kravchenko@sochi.com \\ ${ }^{2}$ I.Javaxishvili Str. 8, 0102 Tbilisi, Georgia; e-mail: g.iremashvili@ddn.ge \\ ${ }^{3}$ Zoological Institute of the Russian Academy of Sciences, Universitetskaya Emb. 1, 199034 Saint Petersburg, Russia; \\ e-mail: Tatyana.Petrova@zin.ru
}

\begin{abstract}
The steppe viper was rediscovered in Georgia after 75 years. A comprehensive analysis of external morphology, altitude gradient in habitats, typology of biotopes and genetic analysis revealed a high degree of similarity of populations of the steppe vipers from Azerbaijan, known as Pelias shemakhensis Tuniyev et al., 2013, and from East Georgia. These data were used for comparative study and description of a new subspecies - P. shemakhensis kakhetiensis ssp. nov. The subspecies name is after historical region of Georgia - Kakheti, where a large part of the range is located. In the pattern of recent distribution of $P$. shemakhensis, there are common habitat and climatic characteristics in Georgian and Azerbaijan parts of this its range. Its position among the species complex and relations with other taxa of this complex are discussed. Based on the results of the cluster and discriminant analyses, P. erizeanensis and P. lotievi should be given a subspecies rank, whereas $P$. shemakhensis clearly deserves a species rank. Results of the genetic analysis are opposite: P. shemakhensis and P. erizeanensis are considered as sister species. We continue to share an idea about autochthonous origin for small shield-head vipers of the Caucasus, taking into account their ancient origin in the Caucasian Ecoregion and astonished variety of forms of the "kaznakovi"-complex and "ursinii"-complex both on the Great Caucasus and in the Transcaucasia.
\end{abstract}

Key words: Georgia, new subspecies, Pelias shemakhensis, steppe viper

\section{ПОВТОРНОЕ ОБНАРУЖЕНИЕ СТЕПНОЙ ГАДЮКИ В ГРУЗИИ}

\author{
Б.С. Туниев ${ }^{1 *}$, Г.Н. Иремашвили ${ }^{2}$, Т.В. Петрова ${ }^{1,3}$ и М.В. Кравченко ${ }^{1}$
}

${ }^{1}$ Федеральное государственное бюджетное учреждение Сочинский национальный парк, ул. Московская 21, 354000 Cочu, Pоссия; e-mails: btuniyev@mail.ru, kravchenko@sochi.com

${ }^{2}$ Ул. И. Джавахишвили 8, 0102 Тбилиси, Грузия; e-mail: g.iremashvili@ddn.ge

${ }^{3}$ Зоологический институт Российской академии наук, Университетская наб. 1, 199034 Санкт-Петербург, Россия; e-mail: Tatyana.Petrova@zin.ru

\section{PЕЗЮМЕ}

Спустя 75 лет степная гадюка вновь была обнаружена на территории Грузии. Комплексный анализ внешней морфологии, высотного градиента обитания, типологии биотопов и генетический анализ показали высокую степень сходства популяций степных гадюк из Азербайджана, известных как Pelias shemakhensis Tuniyev et al., 2013, и Восточной Грузии. Полученные материалы были использованы для сравнительного анализа и описания нового подвида шемахинской гадюки - P. shemakhensis kakhetiensis ssp. nov. Подвид на-

\footnotetext{
* Автор-корреспондент / Corresponding author
} 


\begin{abstract}
зван по географическому наименованию исторической области Грузии - Кахетии, в которой расположена большая часть ареала. Рассматривая современное распространение P. shemakhensis, обращает внимание сходство грузинского и азербайджанского кластеров ареала по биотопическому и климатическому факторам. Рассмотрено положение нового подвида в комплексе видов степных гадюк и обсуждаются его отличия от других таксонов этого комплекса. По результатам кластерного и дискриминантного анализов, P. erizanensis и P. lotievi выступили скорее в подвидовом ранге, тогда, как P. shemakhensis четко отделяется в видовом ранге. По результатам генетического анализа получен противоположный результат - P. shemakhensis и P. erizanensis являются сестринскими видами. Мы продолжаем придерживаться мнения об автохтонности мелких щиткоголовых гадюк Кавказа, учитывая их древность в Кавказском экорегионе и поразительное разнообразие форм “kaznakovi”-complex и “ursinii"-complex как на Большом Кавказе, так и в Закавказье.
\end{abstract}

Ключевые слова: Грузия, новый подвид, Pelias shemakhensis, степная гадюка

\section{INTRODUCTION}

A question about the occurrence of the steppe viper in Georgia remained open from the middle of the last century. Previously, this adder seems to be locally abundant there: Dzhanashvili (1951) noted that in 194413 specimens were killed in the distance of $15 \mathrm{~km}$ of the road in the Shirak Steppe. Later, nobody has confirmed the occurrence of the species within Georgia. All special surveys of the vipers in Eastern Georgia had no successful results. For this reason, it was suggested that the steppe viper really inhabited Eastern Georgia earlier, but subsequently became extinct (Muskhelishvili 1968). Thus, the clarification of the possible recent occurrences of this species is actual (Tuniyev et al. 2013).

In this regard, findings of the steppe vipers in 2015 in a number of closely-spaced localities on the Shirak Plateau (Kakhetia, East Georgia) made by G.N. Iremashvili were of great interest, also in the aspect of their taxonomic position and relations with the recently described Pelias shemakhensis Tuniyev et al., 2013 (Tuniyev et al. 2013). A hypothesis about possible belonging of the vipers from Eastern Georgia to the same taxon was considered.

Institutional and other abbreviations. $\mathrm{Az}-$ Azerbaijan; Ge - Georgia; MNKNU - Museum of Nature at V. N. Karazin Kharkiv National University, Kharkiv, Ukraine; SMG - State Museum of Georgia, Tbilisi, Georgia; SNP - Herpetological collection of the Sochi National Park, Sochi Russia; ZIRA - Scientific Center of Zoology and Hydroecology of the National Academy of Sciences of Republic Armenia, Yerevan, Armenia; ZISP - Zoological Institute of the Russian Academy of Sciences, Saint Petersburg, Russia.

\section{MATERIAL AND METHODS}

A total of 65 specimens of vipers from the Caucasian Ecoregion, related to the "ursinii"-complex were examined including seven specimens of the steppe viper from East Georgia. Data on morphology of the type specimen of Pelias shemakhensis (ZISP 21720), as well as ten specimens from Shemakha and two specimens from Demirchi (Azerbaijan), published by Kukushkin et al. (2012) were also used.

77 specimens of vipers from East Georgia, Azerbaijan, Russia (Dagestan) and Armenia were used in statistical, cluster and discriminant analyses. Material is stored in the herpetological collections of the SNP, ZIRA and ZISP (see Table 1). Material is combined according to geographical localities into four samples: 1) Pelias eriwanensis (Reuss, 1933), Armenia; 2) Pelias shemakhensis, Shemakha, Demirchi, Azerbaijan; 3) Pelias cf. shemakhensis, Shirak Plateau, East Georgia; 4) East Pelias lotievi (Nilson et al., 1995), Dagestan, Russia.

Morphological analyses. The methods of traditional morphology were used for morphological characters offered by Nilson and Andrén (2001) with some our modification (Table 2). To eliminate influence of age variation, comparison of adult and juvenile males and females were made separately only on meristic characters (Table 2). Material was studied statistically using standard methods of variation statistics (Lakin 1990) and one of the methods of multidimensional statistics - Canonical Discriminate Analysis (CDA), and cluster analysis (Tyurin et al. 2003) by the package of STATISTICA 6.0 for Windows.

DNA extraction, amplification and sequencing. 23 specimens sampled from 14 localities (Fig. 1) were analyzed. Five sequences of Pelias ebneri (Knoep- 
Table 1. Examined specimens of Pelias spp. See text for abbreviations.

\begin{tabular}{|c|c|c|c|c|c|c|c|c|}
\hline No. & $\begin{array}{l}\text { Tree } \\
\text { No. }\end{array}$ & $\begin{array}{c}\text { Genbank } \\
\text { accession No. }\end{array}$ & Species & $\mathrm{n}$ & Sample & Locality & Date & Collector \\
\hline $\begin{array}{l}\text { ZISP } \\
21720\end{array}$ & - & - & P. shemakhensis & 1 & 2 & $\begin{array}{l}\text { Vicinity of Shemakha, } \\
\text { Azerbaijan }\end{array}$ & 14.04.1974 & L.A.Erukh \\
\hline $\begin{array}{l}\text { SNP } \\
1059\end{array}$ & 420 & MG729486 & $\begin{array}{l}\text { P. shemakhensis } \\
\text { kakhetiensis ssp. nov. }\end{array}$ & 1 & 3 & $\begin{array}{l}\text { Khornabudji Fortress, Shirak } \\
\text { Plateau, Kakhetia, East Georgia }\end{array}$ & 06.2016 & N. Seturidze \\
\hline $\begin{array}{l}\text { SNP } \\
1052\end{array}$ & $\begin{array}{l}399 \\
402\end{array}$ & $\begin{array}{l}\text { MG729487 } \\
\text { MG729488 }\end{array}$ & $\begin{array}{l}\text { P. shemakhensis } \\
\text { kakhetiensis ssp. nov. }\end{array}$ & 4 & 3 & $\begin{array}{l}\text { Vicinity of the Chinkani Village, } \\
\text { Shirak Plateau, Kakhetia, East } \\
\text { Georgia }\end{array}$ & 09.2015 & G.N. Iremashvili \\
\hline $\begin{array}{l}\text { SNP } \\
1053\end{array}$ & 404 & MG729489 & $\begin{array}{l}\text { P. shemakhensis } \\
\text { kakhetiensis ssp. nov. }\end{array}$ & 2 & 3 & $\begin{array}{l}\text { Vicinity of the Chinkani Village, } \\
\text { Shirak Plateau, Kakhetia, East } \\
\text { Georgia }\end{array}$ & 04.2016 & G.N. Iremashvili \\
\hline $\begin{array}{l}\text { ZIRA } \\
40715\end{array}$ & - & - & P. eriwanensis & 1 & 1 & $\begin{array}{l}\text { Tapchan Elakh, above Kakava- } \\
\text { berd Castle, "Khosrov Forest" } \\
\text { Reserve, Ararat Marz, Armenia }\end{array}$ & 06.2011 & A. Malkhasjan \\
\hline $\begin{array}{l}\text { ZIRA } \\
40717\end{array}$ & - & - & P. eriwanensis & 1 & 1 & The same locality & 06.2011 & A. Malkhasjan \\
\hline $\begin{array}{l}\text { ZIRA } \\
40713\end{array}$ & - & - & P. eriwanensis & 1 & 1 & The same locality & 06.2011 & A. Malkhasjan \\
\hline $\begin{array}{l}\text { ZIRA } \\
40718\end{array}$ & - & - & P. eriwanensis & 1 & 1 & The same locality & 06.2011 & A. Malkhasjan \\
\hline $\begin{array}{l}\text { ZIRA } \\
40714\end{array}$ & - & - & P. eriwanensis & 1 & 1 & The same locality & 06.2011 & A. Malkhasjan \\
\hline $\begin{array}{l}\text { ZIRA } \\
40716\end{array}$ & - & - & P. eriwanensis & 1 & 1 & $\begin{array}{l}\text { Jabrail, vicinity of Getatakh and } \\
\text { Lor villages, Sisian, Sjunik Marz, } \\
\text { Armenia }\end{array}$ & 12.05 .2006 & A. Malkhasjan \\
\hline $\begin{array}{l}\text { ZIRA } \\
40721\end{array}$ & - & - & P. eriwanensis & 1 & 1 & The same locality & 12.05 .2006 & A. Malkhasjan \\
\hline $\begin{array}{l}\text { ZIRA } \\
40719\end{array}$ & - & - & P. eriwanensis & 1 & 1 & The same locality & 12.05 .2006 & A. Malkhasjan \\
\hline $\begin{array}{l}\text { ZIRA } \\
40720\end{array}$ & - & - & P. eriwanensis & 1 & 1 & The same locality & 12.05 .2006 & A. Malkhasjan \\
\hline $\begin{array}{l}\text { ZIRA } \\
\mathrm{n} / \mathrm{n}\end{array}$ & - & - & P. eriwanensis & 1 & 1 & The same locality & 12.05 .2006 & A. Malkhasjan \\
\hline $\begin{array}{l}\text { SNP } \\
890\end{array}$ & 43 & MG543319 & P. eriwanensis & 2 & 1 & $\begin{array}{l}\text { Vicinity of Drakhtik Village, } \\
\text { Areguni Ridge, Armenia }\end{array}$ & $19-20.05 .2012$ & S. Tuniyev \\
\hline $\begin{array}{l}\text { SNP } \\
894\end{array}$ & 42 & MG543320 & P. eriwanensis & 1 & 1 & $\begin{array}{l}\text { Branch of Katar Mountain, } \\
\text { above Verin Giratakh Village, } \\
\text { Khustup-Katarsky Ridge, } \\
\text { Sjunik Marz, Armenia }\end{array}$ & 11.05.2012 & B. Tuniyev \\
\hline $\begin{array}{l}\mathrm{ZIRA} \\
\mathrm{n} / \mathrm{n}\end{array}$ & 219 & MG543321 & P. eriwanensis & 3 & 1 & The same locality & - & A. Malkhasjan \\
\hline $\begin{array}{l}\text { ZIRA } \\
708\end{array}$ & - & - & P. eriwanensis & 2 & 1 & $\begin{array}{l}\text { Near Asni Village, southern slope } \\
\text { of Urtz Ridge, Ararat Marz, } \\
\text { Armenia }\end{array}$ & $\begin{array}{c}8 \text { and } \\
18.05 .1939\end{array}$ & S.K. Dal \\
\hline $\begin{array}{l}\text { ZIRA } \\
812\end{array}$ & - & - & P. eriwanensis & 2 & 1 & $\begin{array}{l}\text { Urtz Ridge, Ararat Marz, } \\
\text { Armenia }\end{array}$ & 10.05 .1950 & P.P. Gambarjan \\
\hline
\end{tabular}


Table 1. Continued.

\begin{tabular}{|c|c|c|c|c|c|c|c|c|}
\hline No. & $\begin{array}{l}\text { Tree } \\
\text { No. }\end{array}$ & $\begin{array}{c}\text { Genbank } \\
\text { accession No. }\end{array}$ & Species & $\mathrm{n}$ & Sample & Locality & Date & Collector \\
\hline $\begin{array}{l}\text { ZIRA } \\
615\end{array}$ & - & - & P. eriwanensis & 1 & 1 & $\begin{array}{l}\text { Sukhoy Fontan Settlement, } \\
\text { Akhtynsky (Razdan) District, } \\
\text { Armenia }\end{array}$ & 03.06.1936 & Izmailov \\
\hline $\begin{array}{l}\text { SNP } \\
797\end{array}$ & $\begin{array}{l}170 \\
171 \\
172\end{array}$ & $\begin{array}{l}\text { MG543322 } \\
\text { MG543323 } \\
\text { MG543324 }\end{array}$ & P. eriwanensis & 3 & 1 & Arai-Ler Mountain, Armenia & 08.2008 & S. Balajan \\
\hline $\begin{array}{l}\text { SNP } \\
1049\end{array}$ & 45 & MG543325 & P. eriwanensis & 1 & 1 & Nagorno-Karabakh & 07.2012 & A.L. Agasjan \\
\hline $\begin{array}{l}\text { ZIRA } \\
\mathrm{n} / \mathrm{n}\end{array}$ & 220 & MG543326 & P. eriwanensis & 1 & 1 & Sisian, Sjunik Marz, Armenia & ? & A.L. Agasjan \\
\hline $\begin{array}{l}\text { SNP } \\
733\end{array}$ & 160 & MG729490 & P. lotievi & 3 & 4 & $\begin{array}{l}\text { Vicinity of Shari Village, } \\
\text { Djufudag Ridge, Agulsky } \\
\text { District, Dagestan, Russia }\end{array}$ & 21.08. 2007 & $\begin{array}{l}\text { B. S. Tuniyev, } \\
\text { S. B. Tuniyev }\end{array}$ \\
\hline $\begin{array}{l}\text { SNP } \\
738\end{array}$ & - & - & P. lotievi & 4 & 4 & The same locality & 21.08.2007 & $\begin{array}{l}\text { B. S. Tuniyev, } \\
\text { S. B. Tuniyev }\end{array}$ \\
\hline $\begin{array}{l}\text { SNP } \\
739\end{array}$ & - & - & P. lotievi & 5 & 4 & The same locality & 21.08. 2007 & $\begin{array}{l}\text { B. S. Tuniyev, } \\
\text { S. B. Tuniyev }\end{array}$ \\
\hline $\begin{array}{l}\text { SNP } \\
740\end{array}$ & - & - & P. lotievi & 1 & 4 & The same locality & 21.08. 2007 & $\begin{array}{l}\text { B. S. Tuniyev, } \\
\text { S. B. Tuniyev }\end{array}$ \\
\hline $\begin{array}{l}\text { SNP } \\
743\end{array}$ & - & - & P. lotievi & 1 & 4 & The same locality & 21.08. 2007 & $\begin{array}{l}\text { B. S. Tuniyev, } \\
\text { S. B. Tuniyev }\end{array}$ \\
\hline $\begin{array}{l}\text { SNP } \\
744\end{array}$ & - & - & P. lotievi & 1 & 4 & The same locality & 21.08. 2007 & $\begin{array}{l}\text { B. S. Tuniyev, } \\
\text { S. B. Tuniyev }\end{array}$ \\
\hline $\begin{array}{l}\text { SNP } \\
745\end{array}$ & - & - & P. lotievi & 1 & 4 & The same locality & 21.08. 2007 & $\begin{array}{l}\text { B. S. Tuniyev, } \\
\text { S. B. Tuniyev }\end{array}$ \\
\hline $\begin{array}{l}\text { SNP } \\
746\end{array}$ & - & - & P. lotievi & 1 & 4 & The same locality & 21.08. 2007 & $\begin{array}{l}\text { B. S. Tuniyev, } \\
\text { S. B. Tuniyev }\end{array}$ \\
\hline $\begin{array}{l}\text { SNP } \\
750\end{array}$ & - & - & P. lotievi & 1 & 4 & The same locality & 21.08. 2007 & $\begin{array}{l}\text { B. S. Tuniyev, } \\
\text { S. B. Tuniyev }\end{array}$ \\
\hline $\begin{array}{l}\text { SNP } \\
749\end{array}$ & - & - & P. lotievi & 1 & 4 & $\begin{array}{l}\text { Vicinity of Burshag Village, } \\
\text { Djufudag Ridge, Agulsky } \\
\text { istrict, Dagestan, Russia }\end{array}$ & 21.08. 2007 & B. S. Tuniyev \\
\hline $\begin{array}{l}\text { SNP } \\
735\end{array}$ & - & - & P. lotievi & 20 & 4 & $\begin{array}{l}\text { Vicinity of Ritlyab Village, } \\
\text { Charodinskiy Reservation, } \\
\text { Dagestan, Russia }\end{array}$ & 19.08. 2007 & $\begin{array}{l}\text { B. S. Tuniyev, } \\
\text { S. B. Tuniyev }\end{array}$ \\
\hline $\begin{array}{l}\text { SNP } \\
764\end{array}$ & - & - & P. lotievi & 3 & 4 & $\begin{array}{l}\text { Vicinity of Tidip Village, Shamil } \\
\text { District, Dagestan, Russia }\end{array}$ & 22.06 .2008 & Z. Ismailova \\
\hline $\begin{array}{l}\text { SNP } \\
762\end{array}$ & 144 & MG729491 & P. lotievi & 3 & - & $\begin{array}{l}\text { Verkhnee Gakvari Village, } \\
\text { Dagestan, Russia }\end{array}$ & 02.07.2008 & B. S. Tuniyev \\
\hline $\begin{array}{l}\text { SNP } \\
1075\end{array}$ & 422 & MG729492 & P. lotievi & 1 & - & $\begin{array}{l}\text { Pass Gumbashi, } \\
\text { Karachay-Cherkessia, Russia }\end{array}$ & 23.08.2016 & Kh. U. Aliev \\
\hline
\end{tabular}


Table 1. Continued.

\begin{tabular}{|c|c|c|c|c|c|c|c|c|}
\hline No. & $\begin{array}{l}\text { Tree } \\
\text { No. }\end{array}$ & $\begin{array}{c}\text { Genbank } \\
\text { accession No. }\end{array}$ & Species & $\mathrm{n}$ & Sample & Locality & Date & Collector \\
\hline $\begin{array}{l}\text { SNP } \\
954\end{array}$ & 243 & MG729493 & P. lotievi & 1 & - & $\begin{array}{l}\text { Targim Hollow, Erzi Reserve, } \\
\text { Ingushetia, Russia }\end{array}$ & 18.06.2014 & K. Yu. Lotiev \\
\hline $\begin{array}{l}\text { SNP } \\
901\end{array}$ & 192 & MG729494 & $P$. renardi & 2 & - & $\begin{array}{l}\text { Vicinity of Saratovskaya } \\
\text { Settlement, Krasnodar Territory, } \\
\text { Russia }\end{array}$ & 20.04 .2012 & $\begin{array}{l}\text { I. N. Timukhin, } \\
\text { S. B. Tuniyev }\end{array}$ \\
\hline $\begin{array}{l}\text { SNP } \\
912\end{array}$ & $\begin{array}{l}185 \\
186 \\
187\end{array}$ & $\begin{array}{l}\text { MG729495 } \\
\text { MG729496 } \\
\text { MG729497 }\end{array}$ & P. renardi & 4 & - & $\begin{array}{l}\text { Vicinity of Saratovskaya } \\
\text { Settlement, Krasnodar Territory, } \\
\text { Russia }\end{array}$ & 06.10 .2012 & $\begin{array}{l}\text { B.S. Tuniyev, } \\
\text { S.B. Tuniyev }\end{array}$ \\
\hline $\begin{array}{l}\text { SNP } \\
782\end{array}$ & $\begin{array}{l}201 \\
204\end{array}$ & $\begin{array}{l}\text { MG543327 } \\
\text { MG543328 }\end{array}$ & P. renardi & 5 & 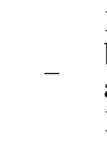 & $\begin{array}{l}\text { Kirista Peninsular, northern } \\
\text { bank of Manych Lake, protected } \\
\text { area of Chernye Zemli Reserve, } \\
\text { Kalmykia, Russia }\end{array}$ & 18.05.2009 & $\begin{array}{l}\text { S.B. Tuniyev, } \\
\text { B.S. Tuniyev }\end{array}$ \\
\hline $\begin{array}{l}\text { SNP } \\
785\end{array}$ & 208 & MG729498 & P. renardi & 2 & - & $\begin{array}{l}\text { Kaban Mountain, vicinity of } \\
\text { Kislovodsk Town, Russia }\end{array}$ & 23.05.2009 & $\begin{array}{l}\text { K.Yu. Lotiev, } \\
\text { S.B. Tuniyev }\end{array}$ \\
\hline
\end{tabular}

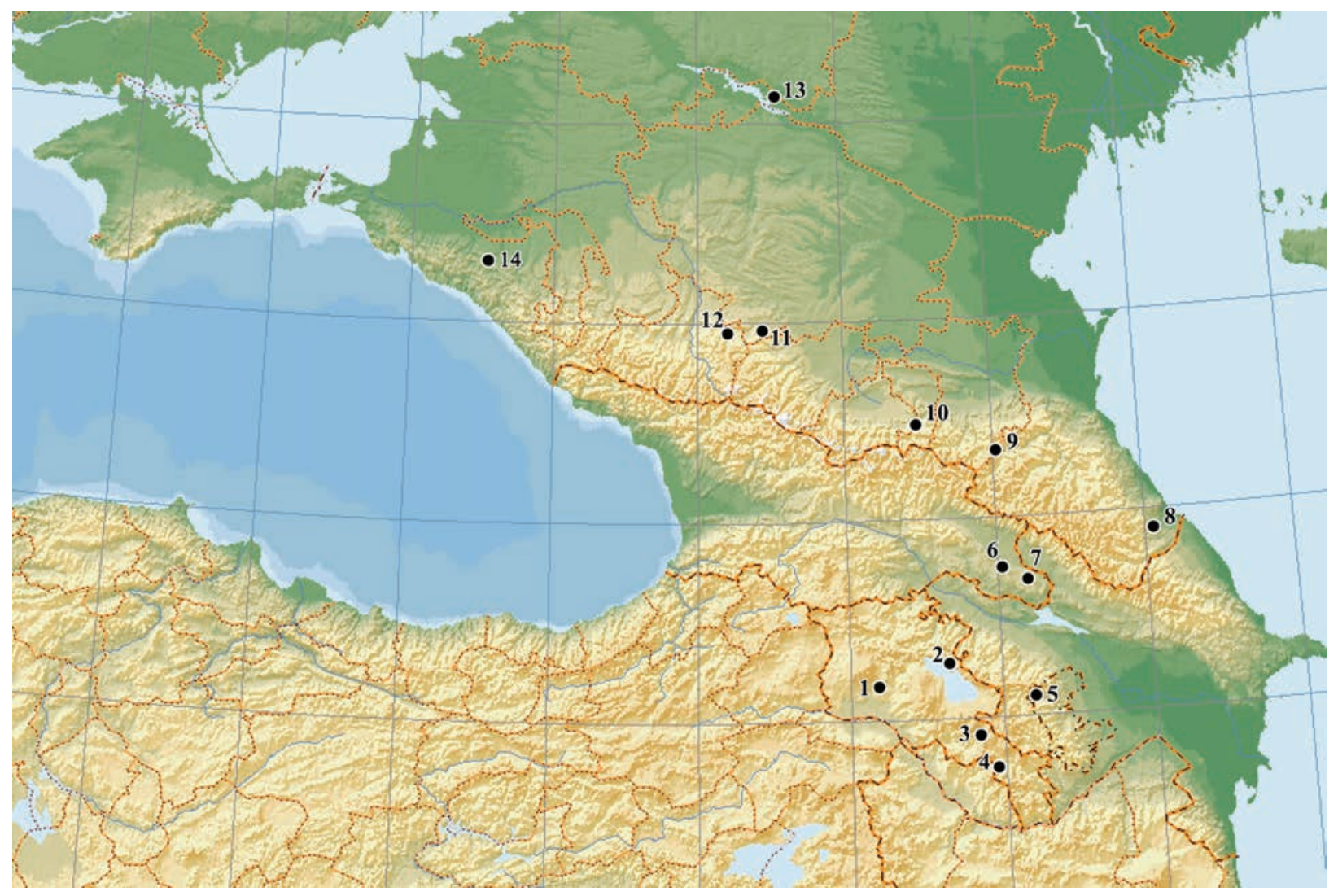

Fig. 1. Localities of Pelias spp. tissue samples for DNA analyses: 1 - Arailer Mountain, Armenia; 2 - Sevan Lake, Drakhtik Village, Armenia; 3 - Sisian, Armenia; 4 - Vicinity of the Verin Giratakh Village, Bargushat Ridge, Armenia; 5 - Nagorno-Karabakh; 6 - Khornabudji Fortress, Georgia; 7 - Chinkani Village, Georgia; 8 - Shari Village, Dagestan, Russia; 9 - Verkhnee Gakvari Village, Dagestan, Russia; 10 - Erzi State Reserve, Ingushetia, Russia; 11 - Kaban Mountain, Stavropol Territory, Russia; 12 - Gumbashi Ridge, KarachayCherkessia, Russia; 13 - Manych-Gudilo Lake, Kalmykia, Russia; 14 - Saratovskaya Settlement, Krasnodar Territory, Russia. 
Table 2. Abbreviations for morphological characters and indexes of vipers.

\begin{tabular}{|c|c|c|}
\hline No. & Abbreviation & Description \\
\hline 1 & T.1. & Total length \\
\hline 2 & SVL & Snout-vent length \\
\hline 3 & L.cd. & Distance from cloaca to tail tip \\
\hline 4 & Pr. & Number of preventral shields \\
\hline 5 & Ven. & Number of ventral shields \\
\hline 6 & S.c. & Number of subcaudal shields \\
\hline 7 & Ap. & Number of apical shields \\
\hline 8 & $\mathrm{R}$. & Rostral index: ratio of height to width \\
\hline 9 & Pil. & Distance from tip of snout to posterior margin of parietal shields \\
\hline 10 & Crown scales (C.s.) & Number of shields, limited by frontals, canthals and supraoculars \\
\hline 11 & In & Upper preoculars in contact with nasal, left/right $(+/-)$ \\
\hline 12 & Can. & Number of canthal shields \\
\hline 13 & Sq.1 & Number of dorsal scales around neck \\
\hline 14 & Sq.2 & Number of dorsal scales around midbody \\
\hline 15 & Sq.3 & Number of dorsal scales around posterior part of body \\
\hline 16 & Supralab. & Number of supralabial shields \\
\hline 17 & Sublab. & Number of sublabials shields \\
\hline 18 & F.c. & Number of shields around eye (left/right) \\
\hline 19 & $\mathrm{ZZ}$ & Number of zigzag windings (left/right) \\
\hline 20 & Lor. & Number of loreal shields (left/right) \\
\hline 21 & L.c. & Head length \\
\hline 22 & Lt.c & Biggest width of head \\
\hline 23 & Al.c. & Height of head in parietal area \\
\hline 24 & Par. & Parietals (hel/delad) \\
\hline 25 & Fr. & Frontal (hel/delad) \\
\hline 26 & Nas. & Nasal (hel/delad) \\
\hline
\end{tabular}

pfler et Sochurek, 1955) were taken from GenBank (KC176745, FR727093-FR727096). Genomic DNA was isolated from tissues fixed with $96 \%$ ethanol using standard salt extraction protocol using a lysis buffer and proteinase $\mathrm{K}$, deproteinized with $\mathrm{NaCl}$ and precipitated with $96 \%$ ethanol (Miller et al. 1988). A segment (1154 bp) of the cytochrome $b(c y t b)$ gene was amplified using primers Cytb_F1 and Cytb_RC, additional internal primer Cytb__F8 was used for sequencing (Stumpel 2012).
PCR conditions were as published in Zinenko et al. (2015). Each PCR included a negative control. The PCR products were purified on columns of an Omnix kit (Omnix, Saint Petersburg, Russia) and were sequenced in both directions using the BigDye Terminator Cycle Sequencing Ready Reaction Kit on an ABI PRISM 3130 (Applied Biosystems Inc., Foster City, CA, USA). Sequences were edited and assembled using program Sequencher 4.6 (Gene Codes Corporation, Ann Arbor, MI, USA http:// 
www.genecodes.com) and aligned with CLUSTALW algorithm (Thompson et al. 1994) implemented in BioEdit (Hall 1999).

Phylogenetic analyses. Tree reconstructions were performed using 28 specimens of Pelias spp. and 3 specimens as outgroup (Bitis arietans (Merrem, 1820) JX114025, Montivipera xanthine (Gray, 1849) KJ415303 and Causus defilippi (Jan, 1863) AY223556). The final alignment comprised the $910 \mathrm{bp} c y t b$ fragment. To choose the best model of molecular evolution $(\mathrm{HKY}+\mathrm{I}+\mathrm{G})$, we used Akaike's information criterion (AIC) in JMODELTEST 2.1.1 (Darriba et al. 2012). Phylogenies were reconstructed using Bayesian inference (BI) and maximum likelihood (ML) approaches. BI for $c y t b$ data performed in MRBAYES 3.2.2 (Ronquist and Huelsenbeck 2003). Each BI analysis started with random trees and performed two independent runs with four Markov chains Monte Carlo (MCMC) for 5 million generations with sampling every 1000th generation. Consensus trees constructed based on the trees sampled after the $25 \%$ burn-in. ML analysis calculated with TREEFINDER (Jobb 2011). Bootstrap analysis employed 1000 replicates. Final trees obtained in FIGTREE v1.4.0 (http://tree.bio.ed.ac. uk/software/figtree/).

The level of genetic differentiation in cytb based on p-distances was estimated in Mega 7 (Kumar et al. 2016). The final alignment for the calculation of p-distances comprised the $663 \mathrm{bp} c y t b$ fragment.

\section{RESULTS OF THE ANALYSES}

\section{Morphological characters}

The taxonomical revisions of the shield-head vipers of the Great Caucasus (Orlov and Tuniyev 1986; Vedmederya et al. 1986; Nilson et al. 1994; Tuniyev and Ostrovskikh 2001) reveal the complicated pattern of cryptic speciation in two lineages of vipers "kaznakovi"-complex and "ursinii"-complex, with morphologically hardly differentiated species mainly in the east sector of the Great Caucasus (Tuniyev S. et al. 2012). A similar pattern is observed in the Transcaucasia, where discrete forms inhabit relatively limited territory, reflecting the prolonged isolation not only for historical reasons, but also due to human activity here since ancient times. On the plains and in the foothills of Eastern Georgia, the intensive use of land for agriculture and livestock has contributed to the extreme fragmentation of habitats for animals whose survival is associated with the conservation of non-plowed steppes.

The steppe vipers found in some localities of the Shirak Plateau in East Georgia seems to belong to relict micropopulations, which are analyzed below.

A comprehensive analysis of external morphology, altitude gradient in habitats, typology of biotopes and genetic analysis revealed a high degree of similarity of populations of the steppe vipers from Azerbaijan, known as Pelias shemakhensis, and from East Georgia. These results allowed to consider newly discovered steppe vipers in Eastern Georgia within the taxa $P$. shemakhensis. However, according to the results of the comparison of the meristic characters between samples of $P$. shemakhensis from East Georgia and Azerbaijan the following differences were recorded (see Tables 3 and 4).

Males. Significant differences were obtained for the number of subcaudals, which is higher in the vipers from Georgia. However, the overall trend is observed for pholidosis oligomerization from West to East from populations of East Georgia to the population from Azerbaijan.

Females. The higher number of subcaudals in males was recorded in the vipers from Georgia too. In addition, the higher number of scales around midbody (Sq.2) was noted in the vipers from Georgia.

Table 3. Comparison of morphological characters of males of Pelias shemakhensis from populations from East Georgia and Azerbaijan. See Table 2 for abbreviations.

\begin{tabular}{|c|c|c|c|c|}
\hline Character & $\begin{array}{c}\text { Mean } \\
\text { P. shemakhensis } \\
\text { East Georgia } \\
\widehat{\partial} \widehat{ठ}\end{array}$ & $\begin{array}{c}\text { Mean } \\
\text { P. shemakhensis } \\
\text { Azerbaijan } \\
\lesssim \widehat{O}\end{array}$ & t-value & $\mathrm{p}$ \\
\hline Pr. & 2.0 & 2.5 & 1.88982 & $>0.05$ \\
\hline Ven. & 135.2 & 134.0 & 1.22988 & $>0.05$ \\
\hline S.c. & 35.2 & 33.0 & 2.68373 & $<0.05$ \\
\hline Ap. & 1.2 & 1.0 & 0.59761 & $>0.05$ \\
\hline C.s. & 13.2 & 12.5 & 0.29111 & $>0.05$ \\
\hline $\mathrm{Sq} 2$ & 21.4 & 21.0 & 0.59761 & $>0.05$ \\
\hline Supralab. & 18.2 & 18.0 & 0.59761 & $>0.05$ \\
\hline Sublab. & 19.8 & 20.0 & 0.59761 & $>0.05$ \\
\hline F.c. & 19.8 & 17.5 & 1.82862 & $>0.05$ \\
\hline $\mathrm{ZZ}$ & 117.0 & 106.0 & 0.81582 & $>0.05$ \\
\hline Lor. & 9.8 & 9.0 & 0.52164 & $>0.05$ \\
\hline
\end{tabular}


Table 4. Comparison of morphological characters of females of Pelias shemakhensis from populations from East Georgia and Azerbaijan. See Table 2 for abbreviations.

\begin{tabular}{|c|c|c|c|c|}
\hline Character & $\begin{array}{c}\text { Mean } \\
\text { P. shemakhensis } \\
\text { East Georgia } \\
\text { 우우 }\end{array}$ & $\begin{array}{c}\text { Mean } \\
\text { P. shemakhensis } \\
\text { Azerbaijan } \\
\text { 우우 }\end{array}$ & t-value & $\mathrm{p}$ \\
\hline Pr. & 1.5 & 1.7 & 0.38069 & $>0.05$ \\
\hline Ven. & 139.5 & 134.9 & 1.74815 & $>0.05$ \\
\hline S.c. & 29.0 & 26.3 & 2.34473 & $<0.05$ \\
\hline Ap. & 1.0 & 0.9 & 0.43033 & $>0.05$ \\
\hline C.s. & 16.0 & 13.3 & 1.12441 & $>0.05$ \\
\hline $\mathrm{Sq} 2$ & 21.5 & 21.0 & 2.88675 & $<0.05$ \\
\hline Supralab. & 19.5 & 18.0 & 8.66025 & $<0.001$ \\
\hline Sublab. & 19.5 & 21.0 & 1.50756 & $>0.05$ \\
\hline F.c. & 18.5 & 18.8 & 0.23973 & $>0.05$ \\
\hline $\mathrm{ZZ}$ & 109.5 & 109.6 & 0.01082 & $>0.05$ \\
\hline Lor. & 13.5 & 10.1 & 2.10697 & $>0.05$ \\
\hline
\end{tabular}

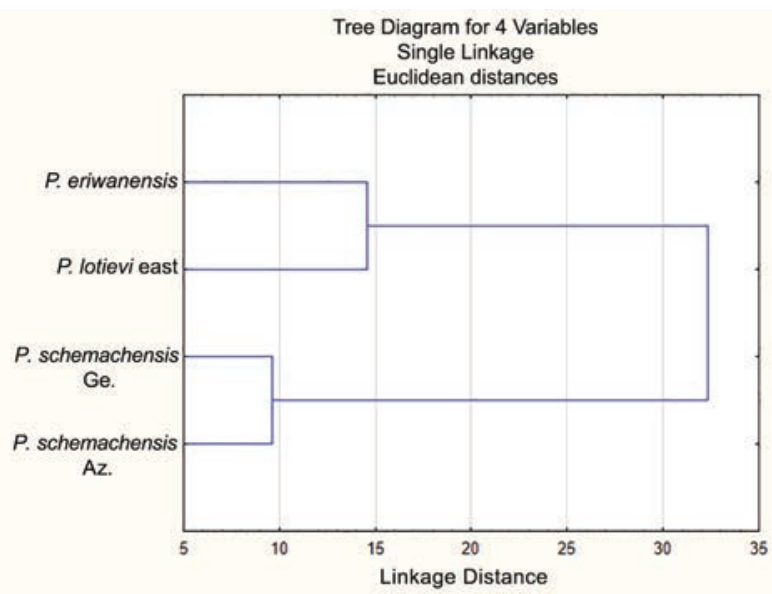

Fig. 2. Results of the cluster analysis (UPGMA method) of four groups of males of Pelias spp. based on pholidosis characters.

The pholidosis oligomerization was registered from West to East: from populations of East Georgia to the population from Azerbaijan.

With regard to the heterogeneity and the low number of individual samples, sexual dimorphism in the populations studied is expressed in different sets of characters. Below we consider these characters for each population (see Tables 5 and 6 ).

Pelias shemakhensis, East Georgia $(n=7)$. The number of subcaudal shields (S.c) and wings of zigzag

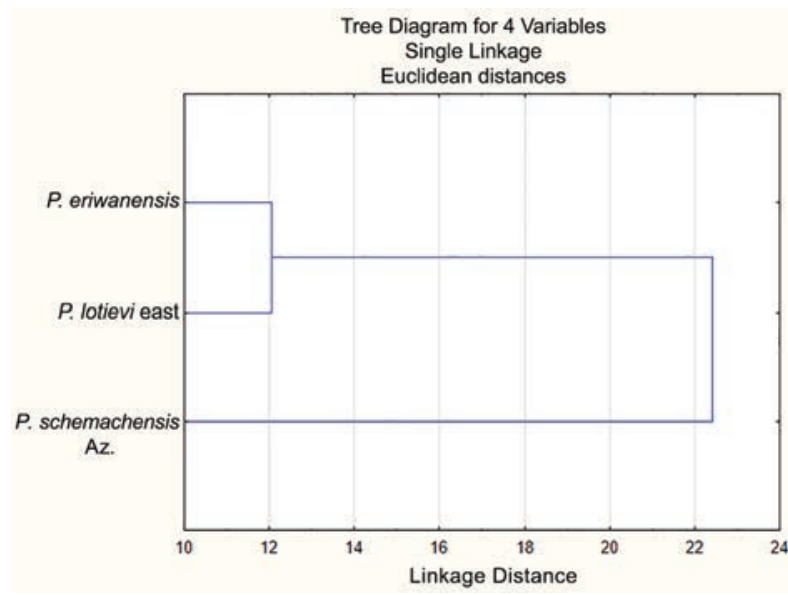

Fig. 3. Results of the cluster analysis (UPGMA method) of four groups of females of the steppe vipers based on pholidosis characters.

(ZZ) are higher in males than in females, while the number of ventral shields (Ventr.), supralabial shields (Supralab.) and number of dorsal scales around the posterior part of body (Sq3) is lower in males than in females.

Pelias shemakhensis, Azerbaijan $(\mathrm{n}=12)$. The number of subcaudal shield is higher in males than in females.

Due to differences in the method of counting of the number of crown shields (C.s.) and number of supralabials (Supralab.) by Kukushkin et al. (2012) from Azerbaijan and in our sample from Georgia, we eliminated methodologically different data about two indicated characters and utilized only eight meristic characters (Pr., Ven., S.c., Sq.2, Sublab., F.c., ZZ., Lor.) in the cluster and discriminant analyses.

The cluster analysis based on eight meristic characters of pholidosis of the males has resulted in a dendrogram consisting of two big clusters: 1) vipers of mountain areas of the Transcaucasia and North Caucasus; and 2) vipers from the East-Transcaucasia Depression. The first cluster is further divided into subclusters of Pelias eriwanensis and P. lotievi, whereas the second one, into two subclusters, corresponding to two populations of P. shemakhensis (Fig. 2).

The cluster analysis based on eight meristic characters of pholidosis of the females showed absolutely identical results with those of the males (Fig. 3).

The geographical variability of morphological characters in populations of the steppe vipers was also analyzed by CDA, allowing a comparison of the preliminary selected groups in the complex of char- 
Table 5. Sexual dimorphism of Pelias shemakhensis from East Georgia population. See Table 2 for abbreviations.

\begin{tabular}{|c|c|c|c|c|c|c|}
\hline Character & $\mathrm{n} \partial \hat{\sigma}$ & $\frac{\begin{array}{c}\delta \hat{\delta} \\
\min -\max \end{array}}{\mathrm{X} \pm \mathrm{m}}$ & $\mathrm{n}$ 우우 & $\frac{\begin{array}{c}\text { oq } \\
\min -\max \end{array}}{\mathrm{X} \pm \mathrm{m}}$ & t-value & $\mathrm{p}$ \\
\hline Pr. & 5 & $\begin{array}{c}2-2 \\
2 \pm 0\end{array}$ & 2 & $\begin{array}{c}1-2 \\
1.5 \pm 0.7\end{array}$ & 1.88982 & $>0.05$ \\
\hline Ven. & 5 & $\begin{array}{c}134-136 \\
135.2 \pm 1.1\end{array}$ & 2 & $\begin{array}{c}138-141 \\
139.5 \pm 2.1\end{array}$ & 3.76845 & $<0.05$ \\
\hline S.c. & 5 & $\begin{array}{c}34-36 \\
35.2 \pm 0.8\end{array}$ & 2 & $\begin{array}{c}28-30 \\
29 \pm 1.4\end{array}$ & 7.56323 & $<0.001$ \\
\hline Ap. & 5 & $\begin{array}{c}1-2 \\
1.2 \pm 0.4\end{array}$ & 2 & $\begin{array}{l}1-1 \\
1 \pm 0\end{array}$ & 0.59761 & $>0.05$ \\
\hline C.s. & 5 & $\begin{array}{c}10-18 \\
13.2 \pm 3\end{array}$ & 2 & $\begin{array}{c}14-18 \\
16 \pm 2.8\end{array}$ & 1.11803 & $>0.05$ \\
\hline Can. & 5 & $\begin{array}{c}5-6 \\
5.2 \pm 0.4\end{array}$ & 2 & $\begin{array}{c}5-5 \\
5 \pm 0\end{array}$ & 0.59761 & $>0.05$ \\
\hline Sq1 & 5 & $\begin{array}{c}19-21 \\
20.6 \pm 0.9\end{array}$ & 2 & $\begin{array}{l}21-21 \\
21 \pm 0\end{array}$ & 0.59761 & $>0.05$ \\
\hline $\mathrm{Sq} 2$ & 5 & $\begin{array}{c}21-23 \\
21.4 \pm 0.9\end{array}$ & 2 & $\begin{array}{c}21-22 \\
21.5 \pm 0.7\end{array}$ & 0.13894 & $>0.05$ \\
\hline Sq3 & 5 & $\begin{array}{c}17-18 \\
17.2 \pm 0.4\end{array}$ & 2 & $\begin{array}{c}18-19 \\
18.5 \pm 0.7\end{array}$ & 3.04725 & $<0.05$ \\
\hline Supralab. & 5 & $\begin{array}{c}18-19 \\
18.2 \pm 0.4\end{array}$ & 2 & $\begin{array}{c}19-20 \\
19.5 \pm 0.7\end{array}$ & 3.04725 & $<0.05$ \\
\hline Sublab. & 5 & $\begin{array}{c}19-20 \\
19.8 \pm 0.4\end{array}$ & 2 & $\begin{array}{c}19-20 \\
19.5 \pm 0.7\end{array}$ & 0.70321 & $>0.05$ \\
\hline F.c. & 5 & $\begin{array}{c}18-21 \\
19.8 \pm 1.3\end{array}$ & 2 & $\begin{array}{c}18-19 \\
18.5 \pm 0.7\end{array}$ & 1.28593 & $>0.05$ \\
\hline $\mathrm{ZZ}$ & 5 & $\begin{array}{c}103-133 \\
117 \pm 12.3\end{array}$ & 2 & $\begin{array}{c}93-126 \\
109.5 \pm 23.3\end{array}$ & 0.59095 & $>0.05$ \\
\hline Lor. & 5 & $\begin{array}{c}7-12 \\
9.8 \pm 1.9\end{array}$ & 2 & $\begin{array}{c}13-14 \\
13.5 \pm 0.7\end{array}$ & 2.52809 & $>0.05$ \\
\hline
\end{tabular}

acters (Tyurin et al. 2003). For comparison, Pelias lotievi east was taken as an outgroup.

We use a complex of seven meristic characters (Pr., Ven., S.c., Sq.2, Sublab., F.c., Lor.) for which the reliable differences were obtained in the statistical analysis. The vipers were divided a priori into eight sexual and geographical groups.

The results of CDA showed enough high accuracy of the division of the geographical groups. The accuracy for the males is the following: Pelias eriwanensis $-77.8 \%$, P. lotievi east $-100 \%$, P. shemakhensis $\mathrm{Ge}-100 \%$, P. shemakhensis $\mathrm{Az}-100 \%$.

All females showed lower accuracy of the division of geographical groups: Pelias eriwanensis - 46.2\%,
P. lotievi east $-73.7 \%$, P. shemakhensis $\mathrm{Ge}-100 \%$, P. shemakhensis $\mathrm{Az}-90 \%$.

The results of CDA showed that in space of discriminant functions the males formed three groups (Fig. 4): 1) Pelias eriwanensis from Armenia; 2) P. shemakhensis from Azerbaijan and Georgia; 3) P. lotievi east from Dagestan. The separation of the species level on the first discriminant function is present between $P$. lotievi east and P. shemakhensis of Azerbaijan and Georgia, while division P. lotievi east and P. eriwanensis is more clear for the second discriminant function.

The distribution of the females in space of discriminant functions (Fig. 5) looks more heterogeneous with the formation of three independent 


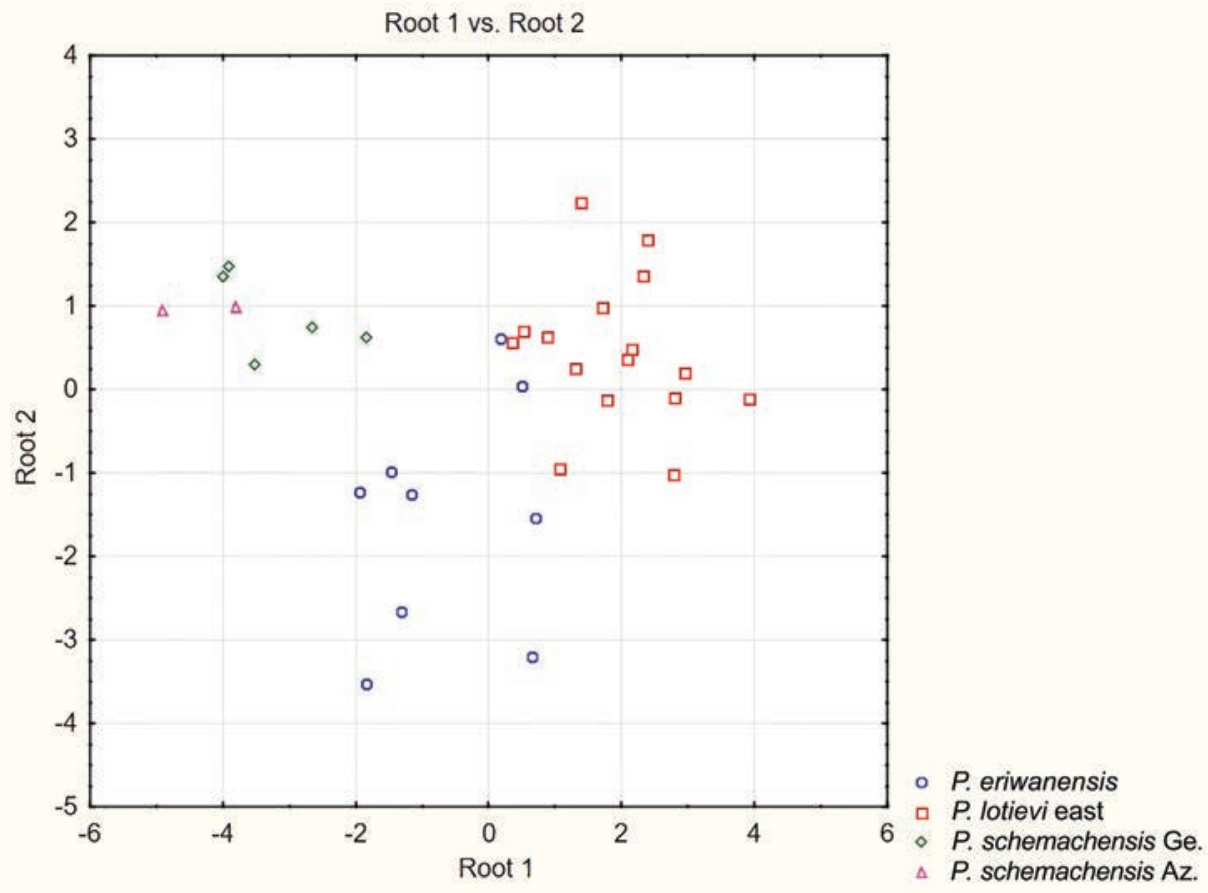

Fig. 4. Two-dimensional scatterplot of samples of males of the steppe vipers in space of CDA function on the complex of morphometric characters.

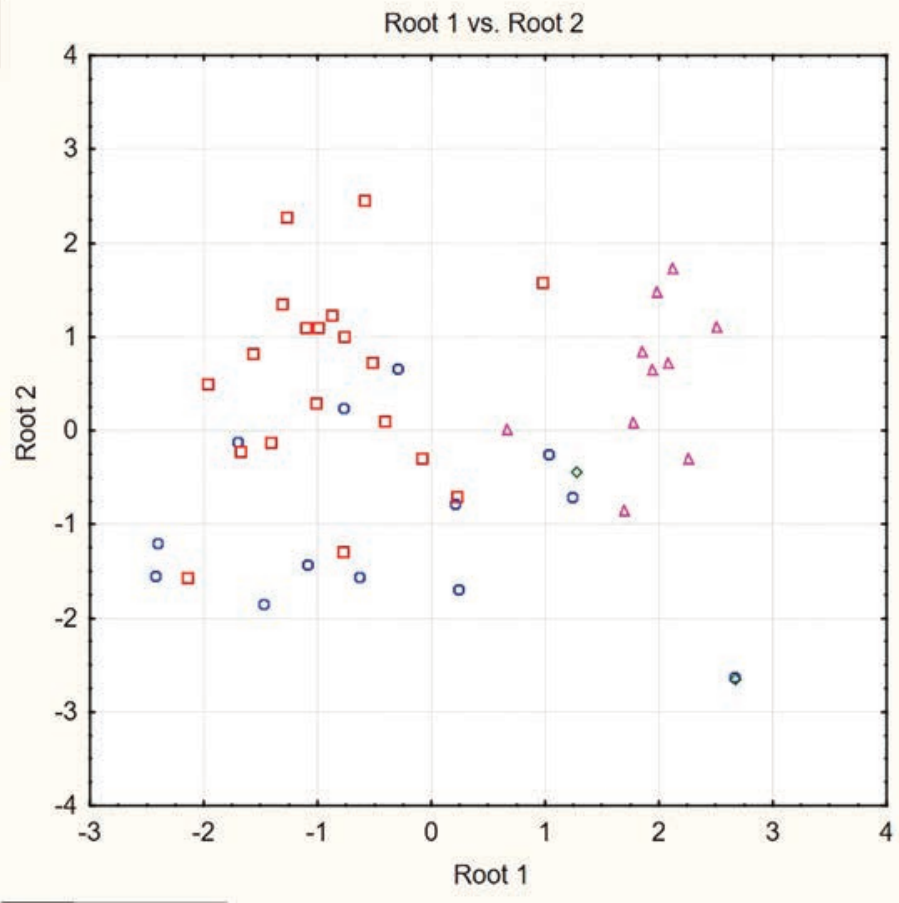

- P. eriwanensis

ㅁ P. lotievi east

- P. schemachensis $\mathrm{Ge}$.

$\triangle P$. schemachensis Az.
Fig. 5. Two-dimensional scatterplot of samples of females of the steppe vipers in space of CDA function on the complex of morphometric characters. 
Table 6. Sexual dimorphism of Pelias shemakhensis from Azerbaijan population. See Table 2 for abbreviations.

\begin{tabular}{|c|c|c|c|c|c|c|}
\hline Character & $\mathrm{n} \partial \hat{\sigma}$ & $\begin{array}{c}\hat{\delta} \\
\frac{\min -\max }{\mathrm{X} \pm \mathrm{m}}\end{array}$ & $\mathrm{n}$ 우우 & $\frac{\begin{array}{c}\text { of } \\
\min -\max \end{array}}{\mathrm{X} \pm \mathrm{m}}$ & $\mathrm{t}$-value & $\mathrm{p}$ \\
\hline Pr. & 2 & $\begin{array}{c}2-3 \\
2.5 \pm 0.7\end{array}$ & 10 & $\begin{array}{c}1-3 \\
1.7 \pm 0.7\end{array}$ & 1.52277 & $>0.05$ \\
\hline Ven. & 2 & $\begin{array}{l}133-135 \\
134 \pm 1.4\end{array}$ & 10 & $\begin{array}{c}129-141 \\
134.9 \pm 3.5\end{array}$ & 0.34580 & $>0.05$ \\
\hline S.c. & 2 & $\begin{array}{c}32-34 \\
33 \pm 1.4\end{array}$ & 10 & $\begin{array}{c}24-29 \\
26.3 \pm 1.5\end{array}$ & 5.81839 & $<0.001$ \\
\hline Ap. & 2 & $\begin{array}{c}1-1 \\
1 \pm 0\end{array}$ & 9 & $\begin{array}{c}0-1 \\
0.9 \pm 0.3\end{array}$ & 0.43033 & $>0.05$ \\
\hline $\mathrm{Sq} 2$ & 2 & $\begin{array}{l}21-21 \\
21 \pm 0\end{array}$ & 10 & $\begin{array}{l}21-21 \\
21 \pm 0\end{array}$ & - & - \\
\hline Sublab. & 2 & $\begin{array}{l}20-20 \\
20 \pm 0\end{array}$ & 10 & $\begin{array}{c}20-23 \\
21 \pm 1.3\end{array}$ & 1.02062 & $>0.05$ \\
\hline F.c. & 2 & $\begin{array}{c}16-19 \\
17.5 \pm 2.1\end{array}$ & 10 & $\begin{array}{c}17-22 \\
18.8 \pm 1.7\end{array}$ & 0.96735 & $>0.05$ \\
\hline $\mathrm{ZZ}$ & 1 & $\begin{array}{c}106-106 \\
106 \pm 0\end{array}$ & 10 & $\begin{array}{c}92-124 \\
109.6 \pm 9.9\end{array}$ & 0.34744 & $>0.05$ \\
\hline Lor. & 2 & $\begin{array}{c}8-10 \\
9 \pm 1.4\end{array}$ & 10 & $\begin{array}{c}6-13 \\
10.1 \pm 2.2\end{array}$ & 0.67018 & $>0.05$ \\
\hline
\end{tabular}

Table 7. Mahalonobis distances (right) and significance levels (left) between samples of males of Pelias eriwanensis, P. lotievi east, $P$. shemakhensis Ge. and P. shemakhensis Az., according to CDA results.

\begin{tabular}{|c|c|c|c|c|}
\hline & P. eriwanensis & P. lotievi east & P. shemakhensis Ge. & P. shemakhensis Az. \\
\hline P. eriwanensis & & 10.36361 & 12.90747 & 22.24767 \\
\hline P. lotievi east & 0.000718 & & 26.58053 & 41.39274 \\
\hline P. shemakhensis Ge. & 0.005897 & 0.000018 & & 6.06630 \\
\hline P. shemakhensis Az. & 0.011396 & 0.000181 & 0.599716 & \\
\hline
\end{tabular}

Table 8. Mahalonobis distances (right) and significance levels (left) between samples of females of Pelias eriwanensis, P. lotievi east, P. shemakhensis Ge. and P. shemakhensis Az., according to CDA results.

\begin{tabular}{|c|c|c|c|c|}
\hline & P. eriwanensis & P. lotievi east & P. shemakhensis Ge. & P. shemakhensis Az. \\
\hline P. erizanensis & & 3.05010 & 11.78868 & 7.679577 \\
\hline P. lotievi east & 0.034834 & & 15.79790 & 8.154632 \\
\hline P. shemakhensis Ge. & 0.063467 & 0.013326 & & 9.672418 \\
\hline P. shemakhensis Az. & 0.000944 & 0.000187 & 0.145138 & \\
\hline
\end{tabular}


Table 9. Contribution of different morphological characters in separation of males of Pelias eriwanensis, P. lotievi east, $P$. shemakhensis Ge., P. shemakhensis Az., according to CDA results. See Table 2 for abbreviations.

\begin{tabular}{ccc}
\hline Character & $\begin{array}{c}\text { Standardized coefficient of } \\
\text { the first discriminant function }\end{array}$ & $\begin{array}{c}\text { Character } \\
\text { rank }\end{array}$ \\
\hline Pr. & 0.25 & 4 \\
Ven. & 0.14 & 7 \\
S.c. & 0.33 & 3 \\
Sq.2 & 0.25 & 5 \\
Sublab. & 0.45 & 2 \\
F.c. & 0.23 & 6 \\
ZZ & 1.03 & 1 \\
Lor. & 0.10 & 8 \\
\hline
\end{tabular}

groups. At that Pelias shemakhensis from Azerbaijan and P. shemakhensis from Georgia are well separated in both discriminant functions, whereas $P$. lotievi east and $P$. eriwanensis are separated only in the second discriminant function.

The species level differences (on the first discriminant function) are noted in Pelias lotievi and $P$. shemakhensis (combined group from Georgia and Azerbaijan), whereas $P$. lotievi east and P. eriwanensis are characterized rather by the subspecies level differences (more clear in the females). Finally, P. shemakhensis from Azerbaijan and P. shemakhensis from Georgia demonstrate only weak population level differences, perhaps due to the small number of samples.

The obtained results confirm the high degree of morphological separation of the compared samples of vipers. Degree of likeness between the selected samples in CDA was estimated as the value of the Makhalonobis distance (Tyurin et al. 2003). The distances between the centers of the samples of the males of vipers varied from 6.1 to 41.4. The minimum value was shown between the males of Pelias shemakhensis from Georgia and P. shemakhensis from Azerbaijan (6.1) and between $P$. lotievi east and P. eriwanensis (10.4), whereas the maximal value (41.4) - between the males of P. shemakhensis from Azerbaijan and P. lotievi east from Dagestan (Table 7). For the females, this distance between the centers of the samples varied from 3.1 to 15.8 . The minimum (3.1) distance was recorded
Table 10. Contribution of different morphological characters in separation of females of Pelias erizonensis, P. lotievi east, P. shemakhensis Ge., P. shemakhensis Az., according to CDA results. See Table 2 for abbreviations.

\begin{tabular}{ccc}
\hline Character & $\begin{array}{c}\text { Standardized coefficient of } \\
\text { the first discriminant function }\end{array}$ & $\begin{array}{c}\text { Character } \\
\text { rank }\end{array}$ \\
\hline Pr. & 0.49 & 2 \\
Ven. & 0.01 & 8 \\
S.c. & 0.06 & 7 \\
Sq.2 & 0.08 & 6 \\
Sublab. & 0.45 & 3 \\
F.c. & 0.22 & 5 \\
ZZ & 0.91 & 1 \\
Lor. & 0.24 & 4 \\
\hline
\end{tabular}

between the females of $P$. lotievi east и $P$. eriwanensis and $P$. shemakhensis from Azerbaijan and P. erizoanensis (8.2); the maximal distance (15.8) - between females P. shemakhensis from Azerbaijan and P. lotievi east from Dagestan (Table 8).

The contribution of different morphological characters to discrimination of the groups is different. Because the first discriminant function takes into account the most percent of the dispersion, and the division of the vipers into main groups occurs exactly along it, the contribution of characters to the division of the groups is described based on values of this function (Tables 9 and 10).

The followings characters made a maximal contribution to discrimination of the groups of the males (Table 9): wings of zigzag (ZZ), sublabials, and subcaudals. The followings characters made a maximal contribution to discrimination of the groups of the females (Table 10): wings of zigzag (ZZ), preventral shields (Pr.), and sublabials.

As a result of our study, new information was obtained about the morphological characters and geographical variability of the three viper species. Substantial differences in the mean values in a number of metric and meristic characters of the vipers are most valuable (Table 3 and 4 ). The discrimination of the three groups into four samples, selected on the principle of geographical and sexual identity using a cluster analysis and CDA (Figs. 2-5; Tables 6-10) is also significant. 
Table 11. Uncorrected p-distances between samples of Pelias spp.

\begin{tabular}{lccccc}
\hline & P. lotievi & P. renardi & P. ebneri & P. shemakhensis & P. eriwanensis \\
\hline P. lotievi & $\mathbf{0 . 0 0 6}$ & & & & \\
P. renardi & 0.011 & $\mathbf{0 . 0 0 5}$ & & & \\
P. ebneri & 0.023 & 0.021 & $\mathbf{0 . 0 0 6}$ & & \\
P. shemakhensis & 0.025 & 0.022 & 0.017 & $\mathbf{0 . 0 0 2}$ & \\
P. eriweanensis & 0.028 & 0.025 & 0.020 & 0.011 & $\mathbf{0 . 0 0 4}$ \\
\hline
\end{tabular}

\section{Genetic analysis}

Cytochrome $b$ tree (Fig. 6) shows the following structure. The main cluster includes Pelias lotievi, $P$. renardi Christoph, 1861 and highly supported cluster $(0.96 \mathrm{BI}$ and $80.3 \mathrm{ML})$ that unites three species: P. ebneri (0.84 BI and 71.4 ML), P. shemakhensis (1.0 $\mathrm{BI}$ and $99.7 \mathrm{ML}$ ) and P. eriwanensis (1.0 BI and 97.5 $\mathrm{ML})$. The $P$. eriwanensis cluster is subdivided into subclusters according to the local populations.

The p-distance between Pelias shemakhensis and P. lotievi is $2.5 \%$, and between P. shemakhensis and P. eriwanensis is $1.1 \%$ (Table 11 ).

The results allow to conclude that the taxonomic differences vary in all four groups, three of which (Pelias eriwanensis, $P$. lotievi east, $P$. shemakhensis) differ on the species level, and two of them ( $P$. shemakhensis $\mathrm{Ge}$, P. shemakhensis $\mathrm{Az}$ ), on the subspecies level.

\section{SYSTEMATICS}

Family Viperidae Laurenti, 1768

Genus Pelias Merrem, 1820

Pelias shemakhensis kakhetiensis Tuniyev, Iremashvili, Petrova et Kravchenko ssp. nov.

Holotype. SNP 1059, vicinity of the Dedopliszkaro Village, Fortress Khornabudji, Shirak Plateau (Kakhetia, East Georgia), 06.2016, Coll.: N. Seturidze (Fig. 7).

Paratypes. Six specimens: SNP 1052 (4 juv.), vicinity of the Chinkani Village, Shirak Plateau (Kakhetia, East Georgia), 09.2015, Coll.: G.N. Iremashvili (Figs. 5 and 6); SNP 1053 (2 specimens, adult mail and adult female), vicinity of the Chinkani Village, Shirak Plateau (Kakhetia, East Georgia), 04.2016, Coll.: G.N. Iremashvili (Fig. 8A, B).
Diagnosis. Small-sized snake, different from the nominative subspecies by larger numbers of pholidosis characters, first of all, maximum number of subcaudals and supralabials. Apical shields are developed in all specimens, in contrast to the nominative subspecies, some specimens of which have a combination of four canthals in absence of apical (a character unique for the whole Pelias complex). A weakly undulated brown zigzag is located in a gray or brown dorsal background. In adults, extra-large patches and some minor dots on the sides of the body can be present in the posterior third of the body, unlike the nominative subspecies with small dots in 2-3 staggered rows along the whole body (Fig. 9). Crown spot is triangular in shape with a contoured white stripe in front of the frontal shield. Adults have a white stripe becoming less contrast, with the continuing triangular crown spot.

Description of the holotype. Adult male having the following morphological characters: total length (T.l.) $-350 \mathrm{~mm}$, length of tail (L.cd.) $-35 \mathrm{~mm}$. Number of preventrals - 2; ventrals - 134; subcaudals - 35; apical - 1; canthals - 5; crown shields (C.s.) - 5. Upper preocular shield is in contact with nasal. Number of rows of dorsal scales around a neck and at midbody - by 21, and at posterior part of the body -17 , sublabials on the right -10 , on the left -9 , supralabial shields on both sides -9 , shields around eyes -10 from the right and 8 from the left, wings of zigzag - 114, loreals -5 from the right and 4 from the left. Length of the head $-20.3 \mathrm{~mm}$, width $-12.6 \mathrm{~mm}$, height $-8.9 \mathrm{~mm}$, length of pileus (Pil.) $-12.6 \mathrm{~mm}$. Frontal, nasal and parietal shields are not divided. The holotype specimen is grey from above with darkbrown zigzag, whose wings are rounded. On the sides of the body there are extra-large patches, whereas several minor dots are present in the posterior third of the body. Pattern of the head not merges with the 


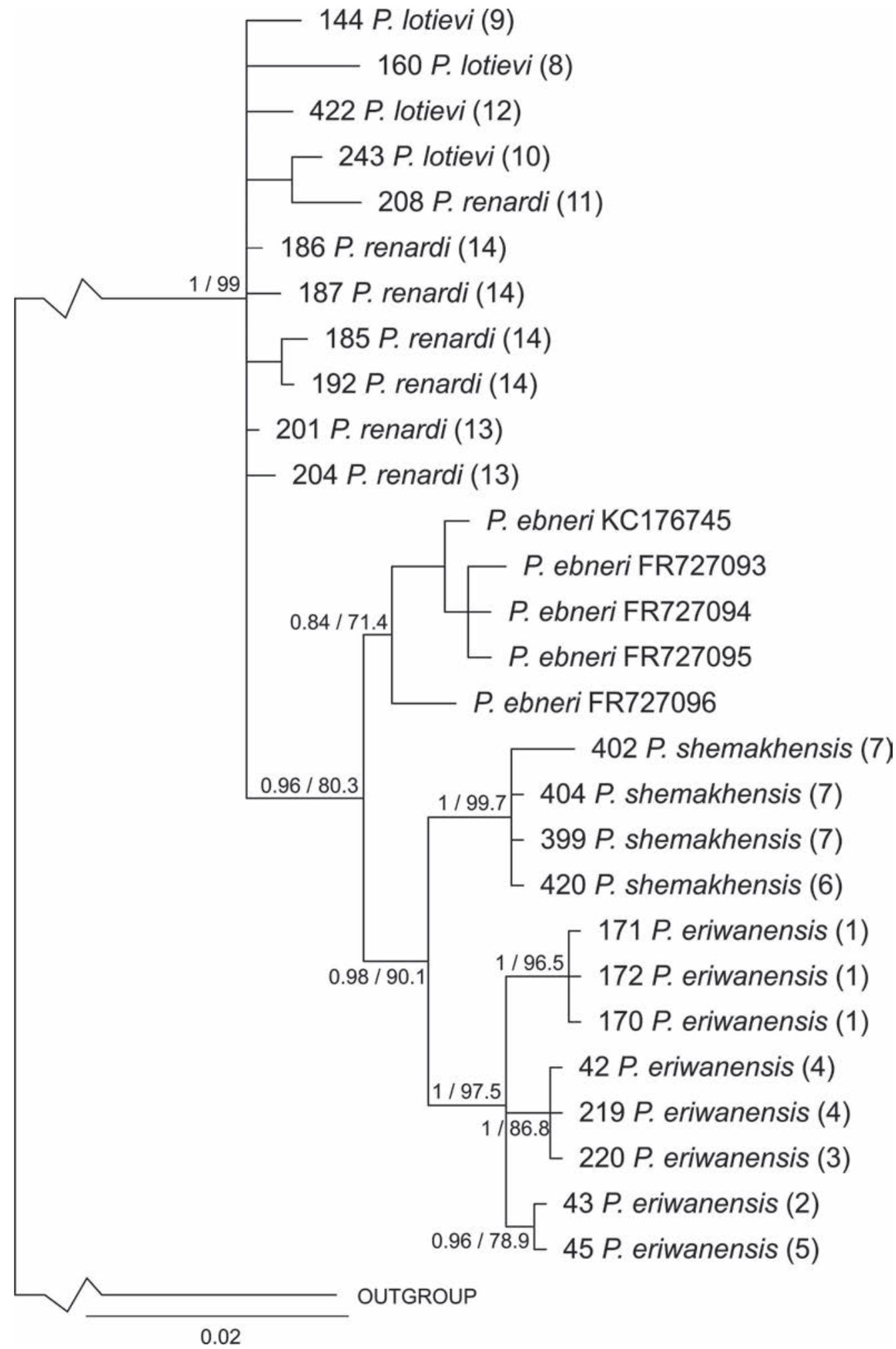

Fig. 6. BI tree for the Pelias spp constructed using cytb haplotypes. Bootstrap values are as follows: Bayesian posterior probabilities / maximum likelihood bootstrap supports. For specimen codes, see Table 1. For location numbers (in brackets), see Fig. 1. 


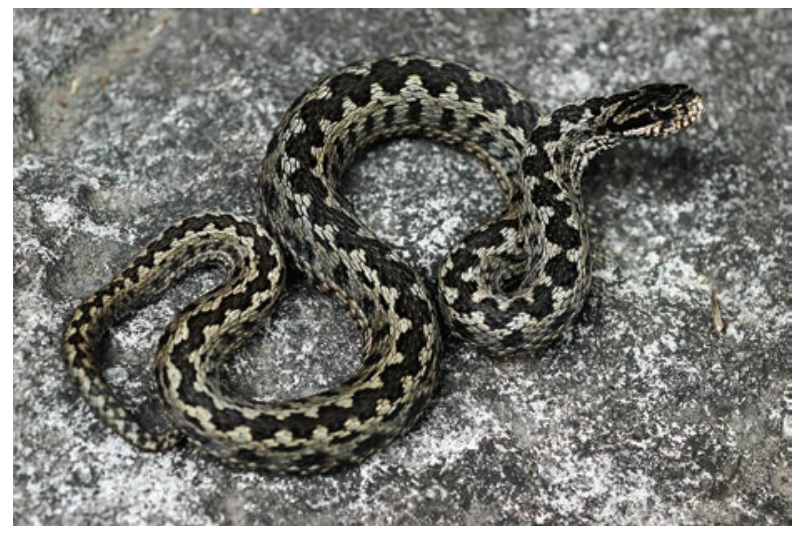

Fig. 7. Holotype of Pelias shemakhensis kakhetiensis ssp. nov. (SNP 1059).

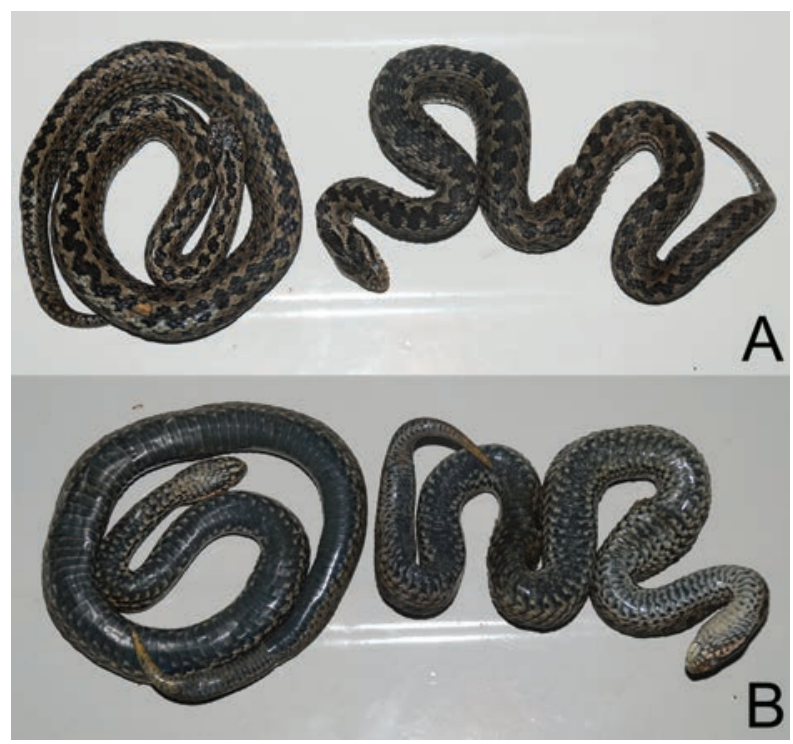

Fig. 8. Part of the type series of Pelias shemakhensis kakhetiensis ssp. nov. (SNP 1053), left - male, right - female: A - view from above; $\mathrm{B}$ - view from below.

zigzag. The crown spot is triangular, contoured by white stripe in front of the frontal shield. Coloring of the throat and lower jaw is light, almost white. Belly and low part of the tail are dark, almost black; the tip of the tail is yellow.

Description of the paratypes. The paratypes are corresponding to description of the holotype with insignificant variations in a size and meristic characters (Table 12).

The main background of adult males is grey, females - grey or pinkish-grey. Zigzag in both sexes continuous, undulating dark brown. Zigzag is separated from pattern of the head. Coloration of juve-

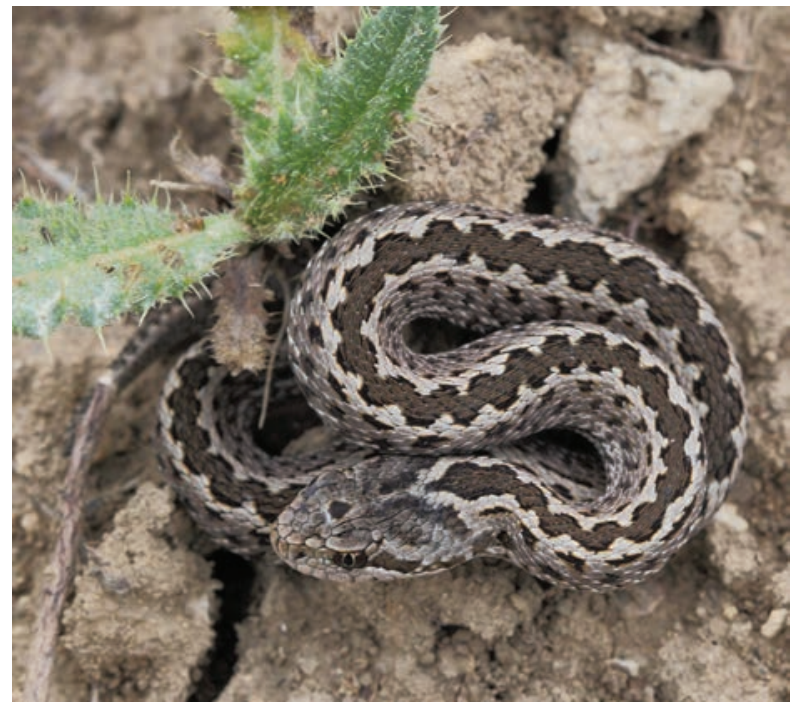

Fig. 9. Nominative subspecies of Pelias shemakhensis (Azerbaijan, vicinity of the Maraza Village) with typical rows of small dots on lateral sides of body.

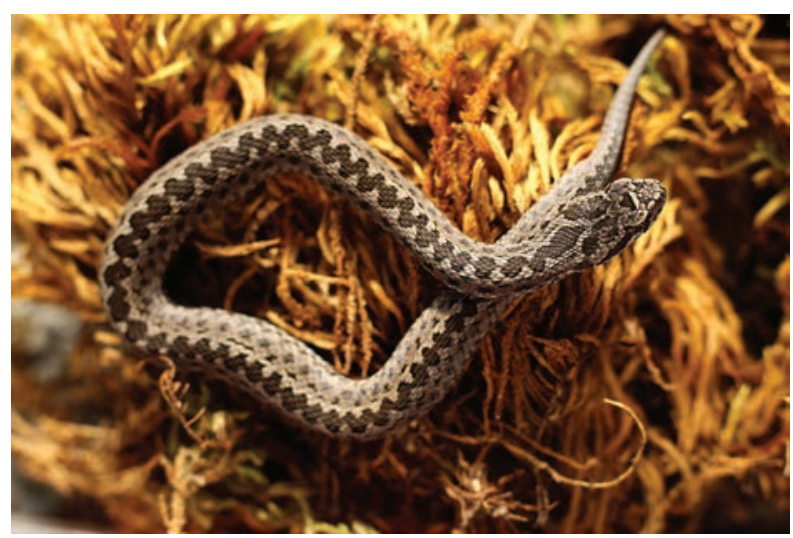

Fig. 10. Color and patterns of the juvenile specimen of Pelias shemakhensis kakhetiensis ssp. nov. (paratype, SNP 1052).

niles is identical to that of the adults, but the characteristic triangular dark patch in the anterior part of the frontal shield with front white stripe, outlined more contrast (Figs. 10 and 11). The coloration of the pileus is dark-brown, almost black in the males. On the sides of the body of the juveniles, there are dots in three rows or one row of dark spots. The adults have extra-large patches on the sides of the body with the second row of several minor dots presented in the posterior third of the body. Coloration of the throat and lower jaw is light, almost white in the adults. The belly in young and adult females is dark spotted, with a predominance of dark tones, whereas in males of 

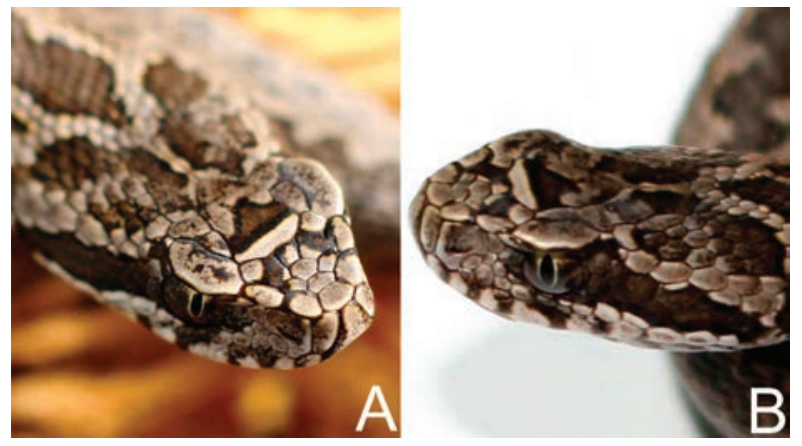

Fig. 11. Heads of two paratype specimens of Pelias shemakhensis kakhetiensis ssp. nov. (SNP 1052; A and B) showing a characteristic triangular dark patch in the anterior part of the frontal shield defined in front by white stripe.

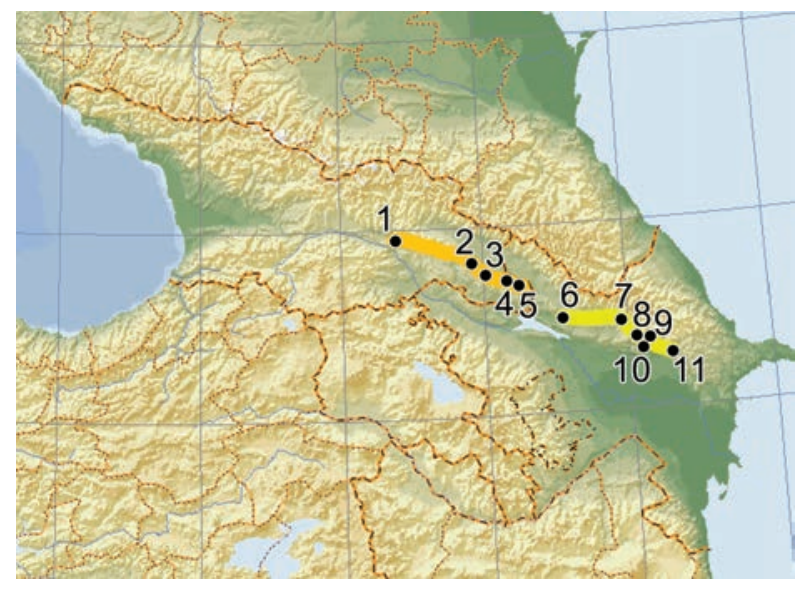

Fig. 12. Distribution of Pelias shemakhensis kakhetiensis ssp. nov. (1-5) and P. shemakhensis shemakhensis (6-11): 1 - Norio Village; 2 - Artsiviskheoba Mountain; 3 - Khornabudji Fortress (Quin Tamar); 4 - Chinkani Village; 5 - Vicinity of the Zemo Kedi Village; 6 - Karatala Village near Nukhi (= Sheki) Town; 7 Demirchi Village; 8 - Khynysly Village; 9 - Angekharan Village; 10 - Shemakha Town; 11 - Maraza Village.

all ages it is almost black; the tip of the tail in both sexes and ages is yellow from below. Dark strips are present, or not in pattern of the front edge of the supralabials; sublabial shields have pattern, reminiscent of the "temminck" figure, but not as contrast as those of Pelias renardi.

Etymology. The subspecies name is after historical region of Georgia - Kakheti, where a large part of the range is located.

Geographical distribution and biotopes. The distribution range of the species in Georgia (Fig. 12) covers the peripheral areas of the Shirak Plateau in two neighboring regions - vicinity of the Chinkani

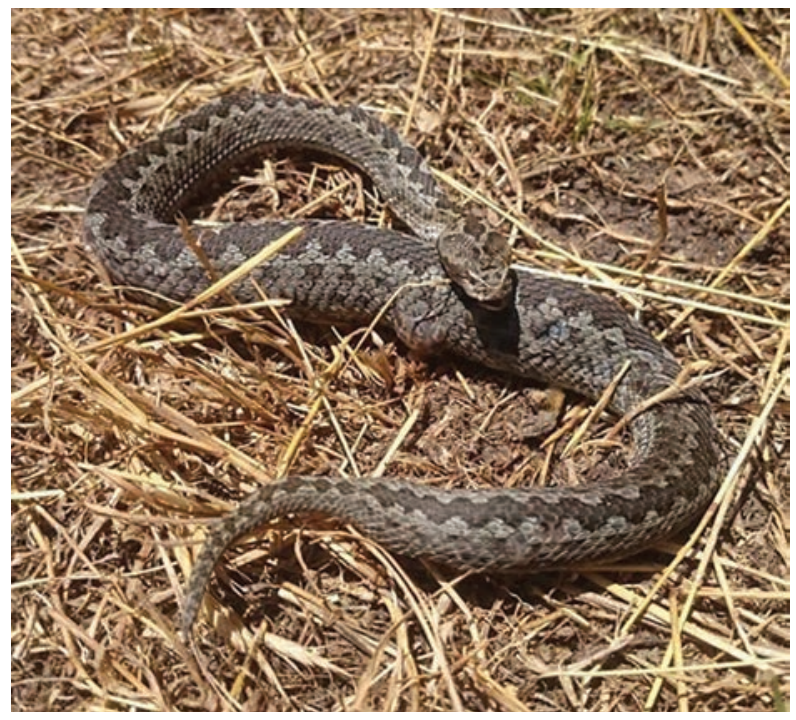

Fig. 13. Killed specimen of Pelias shemakhensis kakhetiensis ssp. nov., Artsivis Kheoba Mountain.

Village and Zemo Kedi Village; in vicinity of the Dedopliszkaro Village near the Khornabudji Fortress, also known as the Fortress of Queen Tamar; at north foot of the mountain Artsivis Kheoba (Fig. 13). In the collection of the SMG, there is specimen from the vicinity of the Norio Village (SMG 125, year 1933, unnamed collector), which represents the western limit of the distribution of the species in Georgia (Fig. 14).

Recent distribution of the nominative subspecies is limited by the Shemakha District of Azerbaijan, from where it is known from vicinity of Shemakha Town, Demirchi Village; Gobustan District - Maraza Village. Alekperov (1978) noted records of the nominative subspecies in the town of Shemakha, between Shemakha and Angekharan Village, between Shemakha and Khynysly Village, at the foot of the Pirdirechidag Mountain, on the slopes of the Gyzkalasy Mountain. For the first time, it was recorded in Azerbaijan near Karatala Village in vicinity of town Nukhi (Nikolsky, 1913), formerly a part of Georgia.

Both preserved fragments of its former distribution area in Georgia and Azerbaijan are clearly the relic (Fig. 12).

Like in Azerbaijan, the biotopes of the species are represented by shibliaks of Paliurus spina-christi, ecotones of dry Andropogon steppes and derivates of the broad-leaved forests on the stony slopes of foothills of the Shirak Plateau in East Georgia (Fig. 15), since 


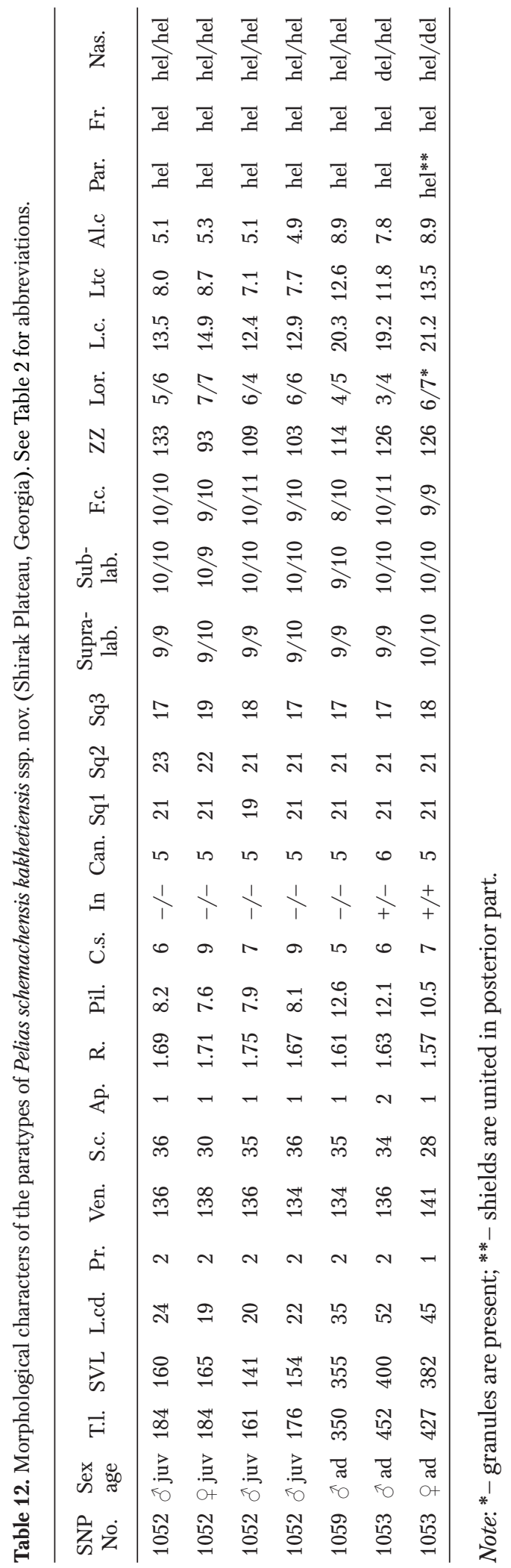

the entire central part of the Shirak Plateau is opened and used for the cultivation of crops (Fig. 16). In other words, in East Georgia the vipers penetrated now from steppes habitats into the biotopes unusual for them or to areas of the broad-leaved forests. The extreme variant of the broad-leaved forests degradation is a Paliurus shibliak. In addition to ploughing of the Shirak Plateau, it is worth mentioning a high anthropogenic press from grazing on the edge parts of not ploughing area of the Shirak Plateau.

\section{DISCUSSION}

The vipers from the North-Eastern Azerbaijan and East Georgia were traditionally referred to Pelias renardi (Muskhelishvili 1968; Alekperov 1978; Nilson and Andren 2001; Ananjeva et al. 2006; Tuniyev et al. 2009), along with the vipers of the northern slopes of the central and eastern part of the Great Caucasus and around the Ciscaucasia.

Later it was suggested (Kukushkin et al. 2012) to refer these vipers to Pelias eriwanensis. In addition, several records from south-western Georgia and northeastern Turkey were included in the distribution range of $P$. eriwanensis. Earlier (Vedmederya et al. 2007) two specimens from Shemakha (MNKNU 27070, G-148) were also identified as Vipera (Pelias) eriwanensis.

After describing Pelias shemakhensis (Tuniyev S. et al. 2013), we suggested that this species belongs to steppe vipers, previously reported from East Georgia. We found P. eriwanensis in the depression of the Kartsakhi Lake in Javakheti part of the Armenian Highland (Southwest Georgia) (Tuniyev S. et al. 2014).

In the pattern of recent distribution of Pelias shemakhensis, there are common habitat and climatic characteristics in Georgian and Azerbajan parts of this its range.

According to the physical-geographical subdivision, the Shirak Plateau refers to the Kura-Alazani Subprovince of the Kura Province of the Transcaucasian Depression Region (Devdariani 1986), while the Shemakha-Gjurdzhivan Plateau belongs to the Kakhetino-Sheki Subprovince of the Eastern Province of the Great Caucasus area of the Great Caucasus Region (Museibov 1986).

The Shemakha-Gjurdzhivan Plateau has altitude 600-800 (up to $1000 \mathrm{~m}$ ) above s.l. with steep terrain and wave-hill terrain of the canyons of the rivers. The average January temperature is $-3^{\circ} \mathrm{C}$, the ab- 


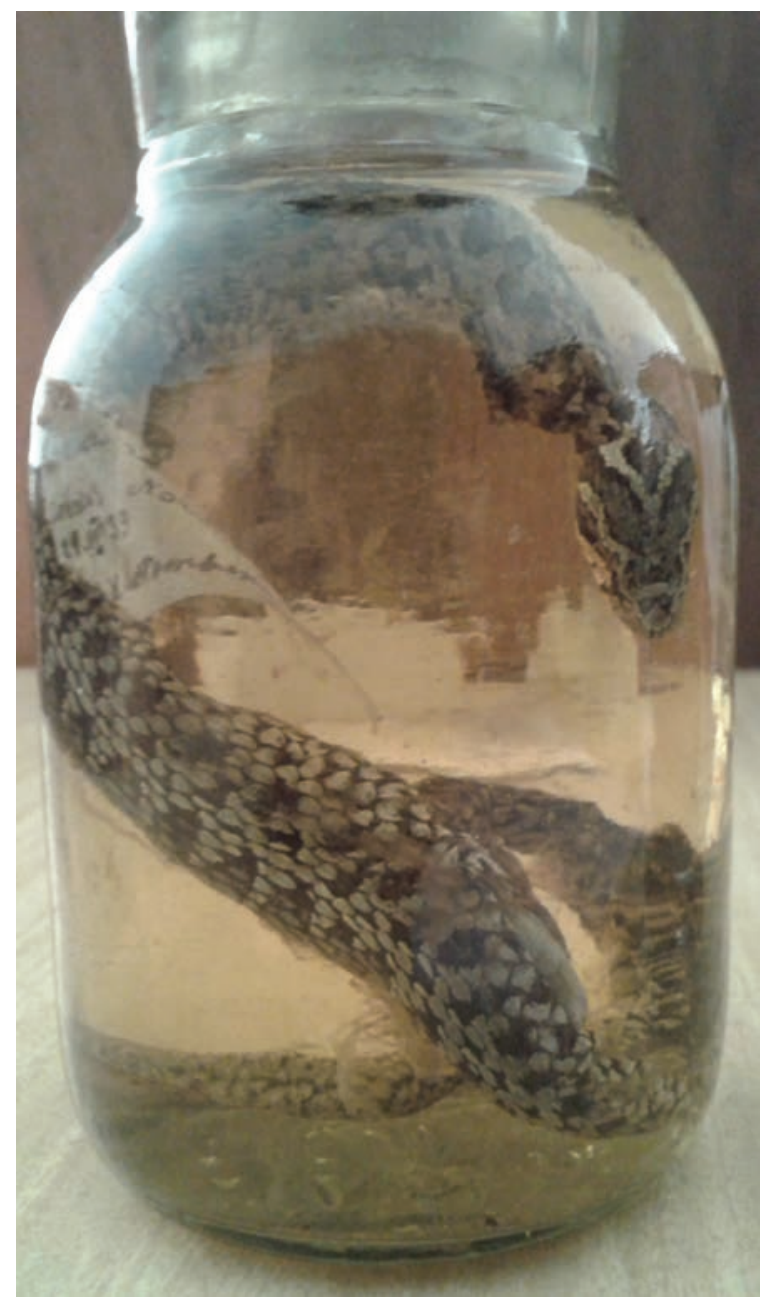

Fig. 14. Pelias shemakhensis kakhetiensis ssp. nov. (SMG 125) from vicinity of the Norio Village.

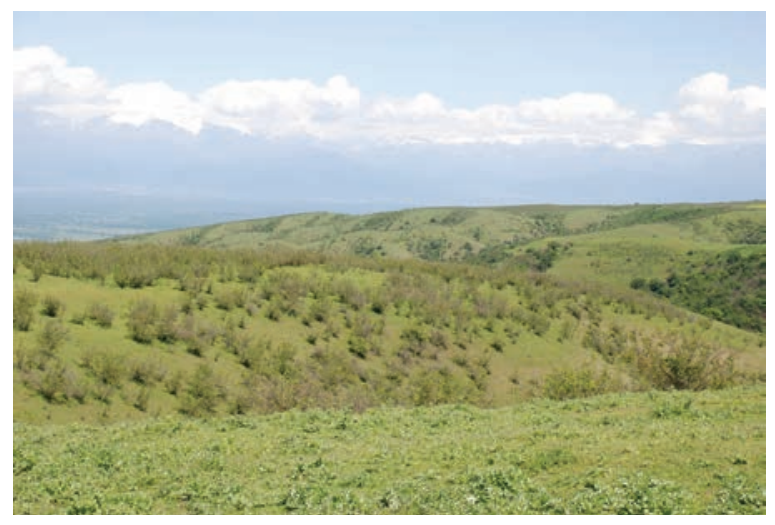

Fig. 15. Biotopes of Pelias shemakhensis kakhetiensis ssp. nov. near the Chinkany Village: shibliaks of Paliurus spinachristy and ecotones of dry Andropogon steppes and derivates of the broad-leaved forests.

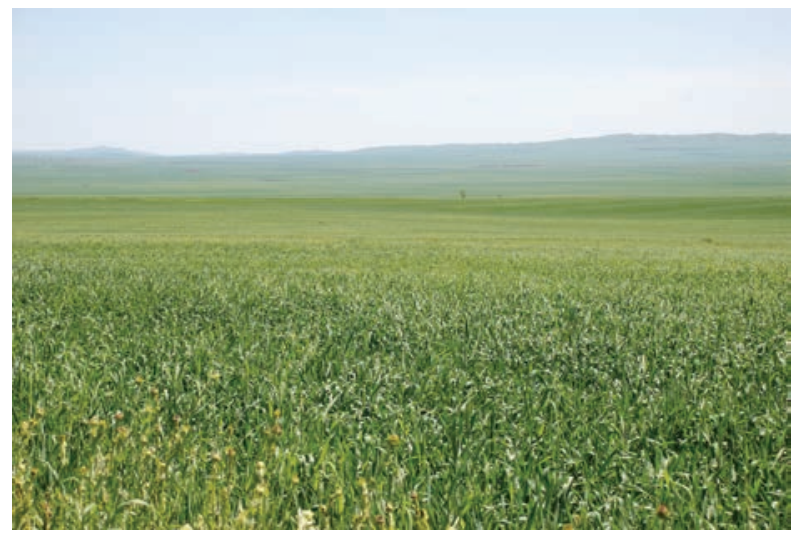

Fig. 16. The entire central part of the Shirak Plateau (Didi Shiraki) plowed and cultivated for crops.

solute minimum is $-22^{\circ} \mathrm{C}$, with an average absolute minimum of $-14^{\circ} \mathrm{C}$. The average annual rainfall is 450-600 mm.

The Shirak Plateau has an altitude of $865 \mathrm{~m}$ above s.l. with the predominance of wave-hill terrain and steep dumping of the Alazani Valley. The average temperature in January is $3.2^{\circ} \mathrm{C}$, with the absolute minimum of $-32^{\circ} \mathrm{C}$. The average temperature in July is $22.8^{\circ} \mathrm{C}$, the absolute maximum is $38^{\circ} \mathrm{C}$. The average annual temperature is $10.3^{\circ} \mathrm{C}$. The average annual precipitation is $490 \mathrm{~mm}$.

Both plateaus are currently woodless, derivatives of forests are found on the steep slopes of the boundary areas, whereas the plain parts of the plateaus are covered by shibliaks of Paliurus spina-christy, secondary dry Andropogon steppes and agricultural crops.

The Shirak Plateau is separated from the Shemakha-Gjurdzhivan Plateau by the Alazani-Agrichaj Plain, with a length of about $300 \mathrm{~km}$, with a width of $20-25 \mathrm{~km}$. In the past, it was fully covered with deciduous forests, which was a natural barrier for penetration of the steppe and semi-desert species of plants and animals.

In the Shirak Plateau, Pelias shemakhensis prefers to inhabit the most elevated northern peripheral sites, the fact also noted by E.S. Balavadze (1966). This author indicated that the steppe viper belongs to the reptiles, inhabiting the specific zone and not penetrating to another sites on the Shirak Plateau. Balavadze (1966) called the steppe viper as "ecological endemic". According to our observations, the species is also found on the rocky slopes of the northern exposure, to the Alazani Valley. 
As was reported previously (Tuniyev S. et al. 2013), on the Shemakha-Gjurdzhivan Plateau, the species also inhabits the rocky slopes covered by shibliaks of Paliurus spina-christi and secondary dry Andropogon steppe.

In biology of Pelias shemakhensis, we marked a unique feature missing from other representatives of the "ursinii"-complex. In summer, the animals change to crepuscular-night activity, which is associated with extremely high daytime air temperatures exceeding $35^{\circ} \mathrm{C}$. So, that adult female (not included in the type series) was observed at 0-30 a.m. (Fig. 17). Alekperov (1978) noted twilight activity of these vipers in the vicinity of Shemakha.

The statistical analysis of the external morphological pholidosis characters shows relatively small differences between animals of two geographical clusters, which are largely determined by the small samples. However, long enough geographic isolation has resulted in the formation of the above marked differences, including elements of the coloring of the body and the head, which allows considering the vipers from the Shirak Plateau in Georgia and the Shemakha-Gjurdzhivan Plateau in Azerbaijan as distinct subspecies. So, Pelias shemakhensis kakhetiensis ssp. nov. does not demonstrate a unique combination of apical and canthal shields missing in other members of the "ursinii complex", but typical for specimens of the nominative subspecies. P. shemakhensis kakhetiensis ssp. nov. has a characteristic triangular dark patch in the anterior part of the frontal shield with a white stripe at the front, whereas the nominative subspecies has a fuzzy dark spot located in the center of the frontal shield. The white stripe in the anterior part of this shield is missing. Differences in the coloration of the body and pholidosis are noted above.

Probably, in the Pliocene, Pelias shemakhensis had a single area, stretching in the steppe and forest-steppe landscapes north of the Transcaucasian Depression from the vicinity of Tbilisi to southeast of the Eastern Caucasus foots. It is known that in the Paleogene of the Caucasus already occur all recent families of the reptiles (Bakradze and Chkhikvadze 1988); thus on the Caucasus and in the nearest environs of this Isthmus lived both mesophylous and various xerophylous species of herpetofauna, identical or closely related to recent species of the Caucasus. Darevsky (1963) considered that by the end of the Pliocene in the Caucasus the primary core of its recent herpetofauna had been formed with such genera as Agama (= aralau-

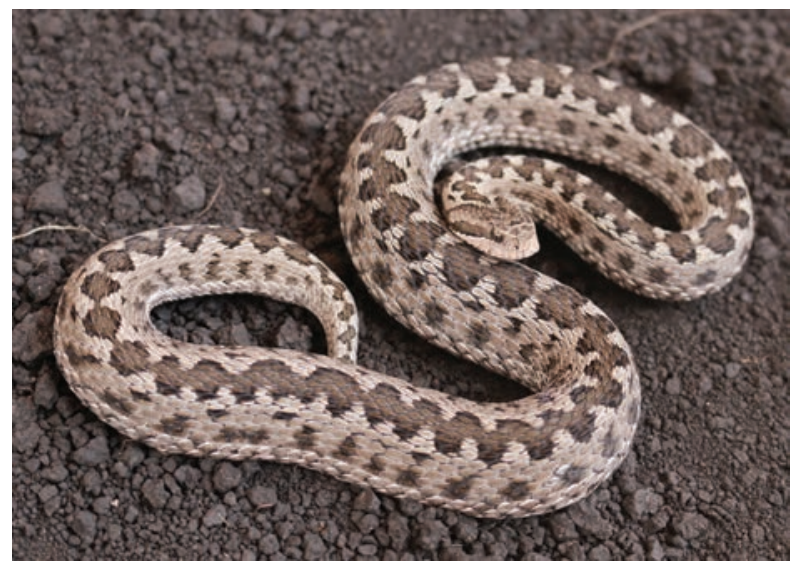

Fig. 17. Adult female of Pelias shemakhensis kakhetiensis ssp. nov. observed at 0-30 a.m. near Chinkani Village.

dakia), Lacerta sensu lato (Darevskia, Lacerta sensu stricto), Ophisaurus (= Pseudopus), Anguis, Typhlops, Malpolon, and Vipera.

The early orogenesis processes intensified in the late Neogene-Quaternary resulted in upraising of flattened surfaces and their dismemberment by canyons. In this period the Pelias shemakhensis range was divided by the Alazani-Agrichaj Plain, completely covered by forest. The further fragmentation of habitats in both clusters took place solely under the influence of human activities, leading to exceptional recent rarities, both the nominative subspecies, and the newly described Pelias shemakhensis kakhetiensis ssp. nov. The inclusion in the Red List of IUCN and Red Data Book of Azerbaijan with status category CR B1ab (i, ii, iii, iv, v) has been requested for the nominative subspecies (Tuniyev S. et al. 2013). The similar status for Pelias shemakhensis kakhetiensis ssp. nov. is required in Georgia.

The main intrigue around Pelias shemakhensis remains in its origin and relationship with other members of the "ursinii"-complex in the Caucasian Isthmus. These questions can be answered based on the results of the cluster, discriminant and genetic analyses provided here.

For the description of Pelias shemakhensis, we used only museum specimens from Azerbaijan (Kukushkin et al. 2012) without genetic analysis.

Based on the results of the cluster analysis of pholidosis characters (Tuniyev S. et al. 2013), the minimum distance was noted between clades of Pelias renardi east, $P$. renardi west and $P$. lotievi, whereas $P$. shemakhensis and P. eriwanensis form sister clus- 
ters. However, results of the discriminant analysis of the evolutionary conservative females suggest that P. shemakhensis (Azerbaijan) and P. lotievi have subspecies rather than species level differences, whereas P. eriwanensis and P. shemakhensis are different on the species level (Tuniyev S. et al. 2013).

Inclusion of the materials from Georgia in the cluster, discriminant and genetic analyses in this paper changed the picture. Based on the results of the cluster and discriminant analyses, Pelias eriwanensis and P. lotievi should be given a subspecies rank, whereas $P$. shemakhensis clearly deserves a species rank. Results of the genetic analysis are opposite: $P$. shemakhensis and P. eriwanensis are considered as sister species.

At present, it is difficult to talk about relationships and distribution routes of ancestors of the entire complex of the steppe vipers. Several conflicting hypotheses were suggested (Zinenko et al. 2011; Ferchaud et al. 2012; Gvozdik et al. 2012; Tuniyev S. et al. 2013) about the routes of distribution of the steppe vipers.

We continue to share the idea about autochthonous origin for small shield-head vipers of the Caucasus (Tuniyev et al. 2013) taking into account their ancient origin in the Caucasian Ecoregion and astonished variety of forms of the "kaznakovi"-complex and "ursinii"-complex both on the Great Caucasus and in the Transcaucasia.

Nilson and Andrén (2001) are very close to this idea, suggesting the hypothetical scenario of origin and distribution of the steppe vipers from the northeast to the southwest and considering the Caucasus as one of Pliocene refugia for the members of the "ursinii" sensu lato. Possibly, genetic analysis of the nuclear DNA will allow coming closer to understanding this issue.

\section{ACKNOWLEDGMENTS}

The authors are greatly indebted to Dr. I.N. Timukhin for field assistance in the North Caucasus and Armenia; to A. Malkhasyan and Dr. A.L. Aghasyan for the permission to examine specimens from Armenia, to Dr. K.Yu. Lotiev for help during fieldwork in the Central Ciscaucasia; to Dr. Igor G. Danilov for critical comments. Finally, this work would be impossible without the great help of Prof. Natalia B. Ananjeva and Prof. Natalia I. Abramson who organized a molecular study in the Laboratory of Molecular Systematic of the Zoological Institute of the Russian Academy of Sciences.

\section{REFERENCES}

Alekperov A.M. 1978. Amphibians and reptiles of Azerbaijan. Elm Publishing, Baku, 262 p. [In Russian].

Ananjeva N.B., Orlov N.L., Khalikov R.G., Darevsky I.S., Ryabov S.A. and Barabanov A.V. 2006. The Reptiles of Northern Eurasia. Faunistica Pensoft Series. Pensoft, Sofia-Moscow, 245 p.

Bakradze M.A. and Chkhikvadze V.M. 1988. Materials on the Tertiary history of the herpetofauna of the Caucasus and the adjoining regions. Vestnik Gosudarstvennogo Muzeya Gruzii, 34a: 176-193. [In Russian].

Balavadze E.A. 1966. Reptiles of Shirak-Eldari and their value in biocenoses. Abstract of the Doctor of Biological Sciences thesis. Baku, 18 p. [In Russian].

Darevsky I.S. 1963. Some peculiarities of herpetofauna of the Caucasian Isthmus in connection with a question on ways of speciation. Abstracts of the III Meeting on Terrestrial Zoogeography, Tashkent, 85-86. [In Russian].

Dedvariani G.S. 1986. Kura-Alasani sub-province. In: G.K. Gabrielyan (Eds). Physical geography of the Transcaucasia. Yerevan State University, Yerevan: 229-233. [In Russian].

Darriba D., Taboada G.L., Doallo R. and Posada D. 2012. jModelTest 2: more models, new heuristics and parallel computing. Nature Methods, 9: 772.

Dzhanashvili A.G. 1951. Materials for studying the distribution of reptiles in Georgia. Trudy Tbilisskogo Gosudarstvennogo Universiteta, 44: 3-19. [In Russian].

Ferchaud A.-L., Ursenbacher S., Cheylan M., Luiselli L., Jelic D., Halpern B., Major A., Kotenko T., Keyan N., Behrooz R., Crnobrnja-Isailovic J., Tomovic L., Ghira I., Ioannidis Y., Arnal V. and Montgelard C. 2012. Phylogeography of the Vipera ursinii complex (Viperidae): mitochondrial markers reveal an east-west disjunction in the Palaearctic region. Journal of Biogeography, 39: 1-12.

Gvozdik V., Jandzik D., Cordos B., Rehak I. and Kotlik P. 2012. A mitochondrial DNA phylogeny of the endangered vipers of the Vipera ursinii complex. Molecular Phylogenetics and Evolution, 62: 1019-1024.

Hall E. R. 1943. Criteria for vertebrate subspecies, species and genera: the mammals. Annals of the New York Academy of Sciences, 44: 141-144.

Jobb G. 2011. TREEFINDER, URL: http://www. treefinder.de/ (accessed on September 15, 2012).

Kukushkin O., Iskenderov T., Ahmedov S., Bunyatova S. and Zinenko O. 2012. Additions to the distribution of Vipera eriwanensis (Serpentes: Viperidae) in Transcaucasia, with comments on the identity of vipers in northeastern Azerbaijan. Herpetology Notes, 5: 423-427.

Kumar S., Stecher G. and Tamura K. 2016. MEGA 7: Molecular Evolutionary Genetics Analysis version 7.0 for bigger datasets. Molecular Biology and Evolution, 33: $1870-1874$. 
Lakin G F. 1980. Biometriya [Biometry]. Vysshaya Shkola, Moscow, 266 p. [In Russian].

Museibov M.A. 1986. Kakhetia-Sheki Sub-Province. In: G.K. Gabrielyan (Eds). Physical geography of the Transcaucasia. Yerevan State University, Yerevan: 208-211. [In Russian].

Muskhelishvili T.A. 1970. Reptiles of Eastern Georgia. Metzniereba, Tbilisi, 235 p. [In Russian].

Nikolsky A.M. 1913. Herpetologia Caucasica. Publishing of Caucasian Museum, Tiflis, 272 p. [In Russian].

Nilson G., Hoggren M., Tuniyev B., Orlov N. and Andren C. 1994. Phylogeny of the vipers of the Caucasus (Reptilia: Viperidae). Zoologica Scripta, 123(4): 353-360.

Nilson G., Tuniyev B.S., Orlov N.L., Hoggren M. and Andrén C. 1995. Systematics of the Vipers of the Caucasus: Polymorphism or Sibling Species? Asiatic Herpetological Research, 6: 1-26.

Nilson G. and Andrén C. 2001. The meadow and steppe vipers of Europe and Asia - the Vipera (Acridophaga) ursinii complex. Acta Zoologica, 47(2-3): 87-267.

Orlov N.L. and Tuniyev B.S. 1986. Modern areas, possible ways of their forming and phylogeny of three species of vipers of Euro-Siberian group of complex Vipera kaznakowi on the Caucasus. Proceedings of Zoological Institute Academy of Sciences of the USSR, 157: 107-135. [In Russian].

Ronquist F. and Huelsenbeck J.P. 2003. MrBayes 3: Bayesian phylogenetic inference under mixed models. Bioinformatics, 19: 1572-1574.

Stümpel N. 2012. Phylogenie und Phylogeographie eurasischer Viperinae unter besonderer Berücksichtigung der orientalischen Vipern der Gattungen Montivipera und Macrovipera. Fakultät für Lebenswissenschaften der Technischen Universität Carolo-Wilhelmina zu Braunschweig, $244 \mathrm{p}$.

Thomson J.D., Higgins D.G. and Gibson T.J. 1994. CLUSTAL W: improving the sensitivity of progressive multiple sequence alignment through sequence weighting, position-specific gap penalties and weight matrix choice. Nucleic Acids Research, 22: 4673-4680.

Tuniyev B.S., Orlov N.L., Ananjeva N.B. and Agasian A.L. 2009. Zmei Kavkaza [Snakes of the Cauca- sus - taxonomical diversity, distribution, conservation]. Saint Petersburg - Moscow, 303 p. [In Russian].

Tuniyev B. S. and Ostrovskikh S. V. 2001. Two new species of vipers of "kaznakovi" complex (Ophidia, Viperinae) from the Western Caucasus. Russian Journal of Herpetology, 8(2): 117-126.

Tuniyev S.B., Orlov N.L., Tuniyev B.S. and Kidov A.A. 2013. On the taxonomical status of steppe viper from foothills of the south macroslope of the East Caucasus. Russian Journal of Herpetology, 20(2): 129-146.

Tuniyev S.B., Iremashvili G.N., Heras B. de las and Tuniyev B.S. 2014. About type locality and finds of Darevsky's viper [Pelias darevskii (Vedmederja, Orlov et Tuniyev, 1986), Reptilia: Viperinae] in Georgia. Russian Journal of Herpetology, 21(4): 281-290.

Tyurin V.V., Morev I.A. and Volchkov V.A. 2003. Linear Discriminant Analysis in Selection of Genetic Research, Krasnodar, 24 p. [In Russian].

Vedmederja V.I., Orlov N.L. and Tuniyev B.S. 1986. On vipers systematic of Vipera kaznakowi complex. Proceedings of the Zoological Institute of the Academy of Sciences of the USSR, 157: 55-61. [In Russian].

Vedmederja V.I., Zinenko A.I. and Goncharenko L.A. 2007. Catalogue of collections of the Kharkov Nature Museum named after V.N. Karazin. Snakes (Reptilia: Serpentes). Kharkov University Publishing, Kharkov, 80 p. [In Russian].

Zinenko O., Stümpel N., Tuniev B.S., Bakiev A.G., Mazanaeva L.F., Kukushkin O.V., Kotenko T.I., Strugariu A., Duisebaeva T., Nilson G., Murphy R., Orlov N.L., Ananyeva N.B. and Joger U. 2011. Phylogeny of small European vipers. Abstracts of European Congress of Herpetology, Luxembourg: 127.

Zinenko O., Stümpel N., Mazanaeva L., Bakiev A., Shiryaev K., Pavlov A., Kotenko T., Kukushkin O., Chikin Y., Duisebayeva T., Nilson G., Orlov N.L., Tuniyev S, Ananjeva N.B., Murphy R.W. and Joger U. 2015. Mitochondrial phylogeny shows multiple independent ecological transitions and northern dispersion despite of Pleistocene glaciations in meadow and steppe vipers (Vipera ursinii and Vipera renardi). Molecular Phylogenetics and Evolution, 84: 85-100.

Submitted May 21, 2018; accepted June 5, 2018. 